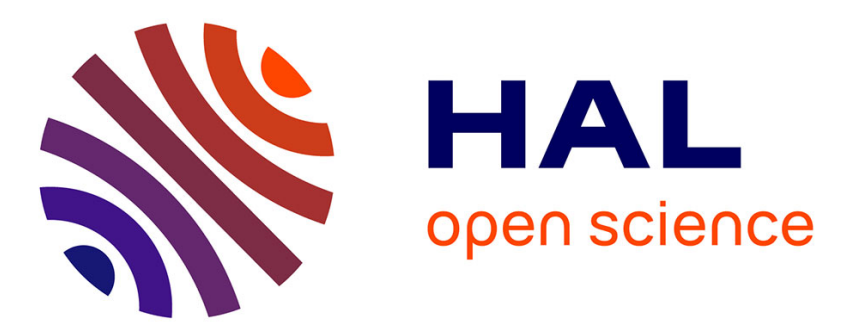

\title{
Ru(II) Polypyridine Complex Functionalized Mesoporous Silica Nanoparticles as Photosensitizers for Cancer Targeted Photodynamic Therapy
}

Johannes Karges, Diana Díaz-García, Sanjiv Prashar, Santiago Gómez-Ruiz, Gilles Gasser

\section{To cite this version:}

Johannes Karges, Diana Díaz-García, Sanjiv Prashar, Santiago Gómez-Ruiz, Gilles Gasser. Ru(II) Polypyridine Complex Functionalized Mesoporous Silica Nanoparticles as Photosensitizers for Cancer Targeted Photodynamic Therapy. ACS Applied Bio Materials, 2021. hal-03198164

\section{HAL Id: hal-03198164 https://hal.science/hal-03198164}

Submitted on 14 Apr 2021

HAL is a multi-disciplinary open access archive for the deposit and dissemination of scientific research documents, whether they are published or not. The documents may come from teaching and research institutions in France or abroad, or from public or private research centers.
L'archive ouverte pluridisciplinaire HAL, est destinée au dépôt et à la diffusion de documents scientifiques de niveau recherche, publiés ou non, émanant des établissements d'enseignement et de recherche français ou étrangers, des laboratoires publics ou privés. 


\section{$\mathrm{Ru}(\mathrm{II})$ Polypyridine Complex Functionalized Mesoporous Silica Nanoparticles as Photosensitizers for Cancer Targeted Photodynamic Therapy}

Johannes Karges, ${ }^{a}$ Diana Díaz-García, ${ }^{b}$ Sanjiv Prashar, ${ }^{b}$ Santiago Gómez-Ruiz ${ }^{b, *}$ and Gilles Gasser $^{a, *}$

a Chimie ParisTech, PSL University, CNRS, Institute of Chemistry for Life and Health Sciences, Laboratory for Inorganic Chemical Biology, 75005 Paris, France.

b COMET-NANO Group, Departamento de Biología y Geología, Física y Química Inorgánica, ESCET, Universidad Rey Juan Carlos, Calle Tulipán s/n, E-28933, Móstoles (Madrid), Spain.

* E-mail: santiago.gomez@urjc.es; https://santiago-gomez-ruiz.webnode.es/comet-nanogroup; Email: gilles.gasser@chimieparistech.psl.eu; www.gassergroup.com; Tel. +331 8578 4151.

ORCID-ID:

Johannes Karges: 0000-0001-5258-0260

Diana Díaz-García: 0000-0003-3057-4905

Sanjiv Prashar: 0000-0002-6588-878X

Santiago Gómez-Ruiz: 0000-0001-9538-8359

Gilles Gasser: 0000-0002-4244-5097

\section{Keywords:}

Anticancer, Bioinorganic Chemistry, Medicinal Inorganic Chemistry, Metals in Medicine, Mesoporous Silica Nanoparticles, Photodynamic Therapy. 


\begin{abstract}
Cancer is the leading cause of death in the developed world. In the last decades, photodynamic therapy (PDT) has augmented the number of medical techniques to treat this disease in the clinics. As the pharmacological active species to kill cancer cells are only generated upon light irradiation, PDT is associated with an intrinsic first level of selectivity. However, since PDT agents are also accumulating in the surrounding, healthy tissue and since it is practically very challenging to only expose the tumor site to light, some side effects can be observed. Consequently, there is a need for a selective drug delivery system, which would give a second level of selectivity. In this work, a dual tumor targeting approach is presented based on mesoporous silica nanoparticles, which act by the enhanced permeability and retention (EPR) effect, and the conjugation to folic acid, which acts as a targeting moiety for folate receptors overexpressed cancer cells. The conjugates were found to be non-toxic in non-cancerous human normal lung fibroblast cells while showing a phototoxic effect upon irradiation at 480 or 540 $\mathrm{nm}$ in the low nanomolar range in folate overexpressing cancerous human ovarian carcinoma cells, demonstrating their potential for cancer targeted treatment.
\end{abstract}




\section{INTRODUCTION}

Photodynamic therapy (PDT) has made its way inside the clinics to treat certain types of cancer. During such a treatment, a photosensitizer (PS) is exposed to a light source to photocatalytically generate reactive oxygen species, which cause cellular damage. ${ }^{1-2}$ Next to tetrapyrrolic compounds, which are currently applied in the clinics, metal complexes, ${ }^{3-6}$ and especially $\mathrm{Ru}(\mathrm{II})$ polypyridine complexes, ${ }^{7-20}$ are extensively studied to complement the existing PDT PSs because of their ideal photophysical and biological properties. Due to the necessity of light activation, PDT treatments have intrinsically a first level of selectivity. However, since the PS accumulates also in healthy tissue and since it is practically impossible to strictly expose only the tumor site to the light source, healthy tissue is damaged during treatment. Consequently, there is a need for cancer selective drug delivery system, which can prevent these side effects and therefore generate a second level of selectivity. ${ }^{21-22}$

The first reported example of a successful drug delivery system was the controlled release of dextroamphetamine (Dexedrine) in 1952. ${ }^{23}$ Following this, increasing attention has been devoted towards the development of drug delivery systems to improve the pharmacological properties of a drug (candidate). ${ }^{24}$ Next to the delivery of the therapeutic to the target, the ability and functions of these carriers evolved over time. Today, drug delivery systems are used to 1) improve water solubility and prevent aggregation, 2) improve chemical stability, 3) enhance the selectivity to its target tissue, organ, cell or cellular compartment and/or 4) reduce or prevent side effects. ${ }^{25-26}$ A variety of different drug delivery systems have been designed. Typically, these are divided between an active or passive targeting strategy. In an active targeting approach, a specific biological interaction is utilized like signaling peptides, ${ }^{27-28}$ oligonucleotides, ${ }^{29-30}$ oligosaccharides, ${ }^{31}$ vitamins, ${ }^{32-33}$ proteins, ${ }^{34-35}$ antibodies $^{36}$ or receptor targeting moieties. ${ }^{37-39}$ On the contrary, in the passive targeting approach, the nature of the tumor tissue is tackled through their poor lymphatic tissue and leaky, highly permeable vasculature properties, also referred to as the enhanced permeability and retention (EPR) effect, ${ }^{40}$ although this concept is currently controversially discussed based to its limitations in in vivo models. ${ }^{41}$ Examples involve the encapsulation into polymeric particles, ${ }^{42-47}$ liposomes ${ }^{48-}$ ${ }^{49}$ or functionalization of nanoparticles based on silver, ${ }^{50}$ gold, ${ }^{51}$ selenium, ${ }^{52-53}$ or silica. ${ }^{54-56}$

Within this context, some attention has been focused on the application of mesoporous silica nanoparticles (MSNs) due to their low price, synthetic accessibility as well as tumor targeting properties. Recent studies have demonstrated the synthetic procedures to covalently attach folic acid to the outer sphere of MSN functionalized organotin(IV) particles as well as showed an 
increased cellular uptake in folate receptor overexpressing cells, presenting its potential as a cancer targeting chemotherapeutic drug delivery system. ${ }^{57-58}$

Capitalizing on this knowledge, in this article, $\mathrm{Ru}(\mathrm{II})$ polypyridine complex functionalized MSNs for cancer targeted PDT are described. The reported approach involves a dual tumor targeting strategy based on 1) MSNs, which are able to accumulate in tumor tissue through the EPR effect; 2) folic acid, which is majorly internalized through folate receptors and are overexpressed in a variety of cancers. To enable a covalent attachment to the particles, the previously reported and highly efficient $\left[\mathrm{Ru}(\mathrm{bphen})_{2}\left(4,4^{\prime}\right.\right.$-dimethyl-2,2'-bipyridine $\left.)\right]\left[\mathrm{PF}_{6}\right]_{2}$ (bphen = 4,7-diphenyl-1,10-phenanthroline) ${ }^{59}$ PS was derivatized with a carboxylic acid (Ru1) or aldehyde group (Ru2) and conjugated to the MSN particles upon amide or imine bond formation, respectively (See Scheme 1). The generated particles were characterized in-depth and biologically evaluated for their potential as cancer targeted PDT agents. Promisingly, the particles demonstrated a cytotoxic effect upon irradiation at 480 or $540 \mathrm{~nm}$ in folate overexpressing cancerous human ovarian carcinoma cells in the low nanomolar range while being non-toxic in human normal lung fibroblast cells, demonstrating their potential for cancer targeted therapy. 


\section{RESULTS AND DISCUSSION}

\section{Synthesis}

The ligands $4^{\prime}$-methyl-2,2'-bipyridinyl-4-aldehyde ${ }^{60}$ and $4^{\prime}$-methyl-2,2'-bipyridinyl-4carboxylic $^{61}$ were synthesized as previously reported by oxidation of 4,4'-dimethyl-2,2'bipyridine with selenium dioxide. The $\mathrm{Ru}(\mathrm{II})$ complex was prepared by reduction of $\mathrm{Ru}(\mathrm{III}) \mathrm{Cl}_{3}$ with ethanol and asymmetric coordination of bphen, yielding the $\mathrm{Ru}(\mathrm{bphen})_{2} \mathrm{Cl}_{2}$ complex. Finally, the bipyridine derivative was coordinated to the Ru(II) center (Scheme S1) upon replacement of the chloride ligands. The $\mathrm{Ru}(\mathrm{II})$ complexes $\left[\mathrm{Ru}(\mathrm{bphen})_{2}\left(4^{\prime}\right.\right.$-methyl-2,2'bipyridinyl-4-carboxylic acid) $\left.]_{[} \mathrm{PF}_{6}\right]_{2}$ (Ru1) and [Ru(bphen)2(4'-methyl-2,2'-bipyridinyl-4aldehyde) $]\left[\mathrm{PF}_{6}\right]_{2}(\mathbf{R u 2})$ were analyzed by ${ }^{1} \mathrm{H},{ }^{13} \mathrm{C}-\mathrm{NMR}$ spectroscopy, HR-MS spectrometry and their purity confirmed by elemental analysis (Figure S1-S6). We note that the two resulting enantiomers were not separated and that the racemic mixture was used in this study.

Mesoporous silica nanoparticles (G-MSN) were synthesized (Scheme 1) by a modified sol-gel method from tetraethyl orthosilicate as a silica precursor in the presence of hexadecyltrimethylammonium bromide as an agent for micelles formation at $80{ }^{\circ} \mathrm{C}$. The particles were functionalized with the polyamino linker $\mathrm{N}^{1}-(3-$ trimethoxysilylpropyl)diethylenetriamine (DETATMS) on the surface and inside the pores upon elimination of methanol by protonolysis of the methoxo groups of the linker to yield the material G-MSN-DETATMS. The targeting moiety folic acid (FA) was covalently attached by amide bond formation through $N$-(3-dimethylaminopropyl)- $N$ '-ethylcarbodiimide coupling, yielding G-MSN-DETATMS-FA. The Ru(II) polypyridine complexes (Ru1 or Ru2) were covalently linked to the MSN particles upon amide bond formation (G-Ru-1 with folic acid, G-Ru-3 without folic acid) or imine bond formation (G-Ru-2 with folic acid, G-Ru-4 without folic acid). 


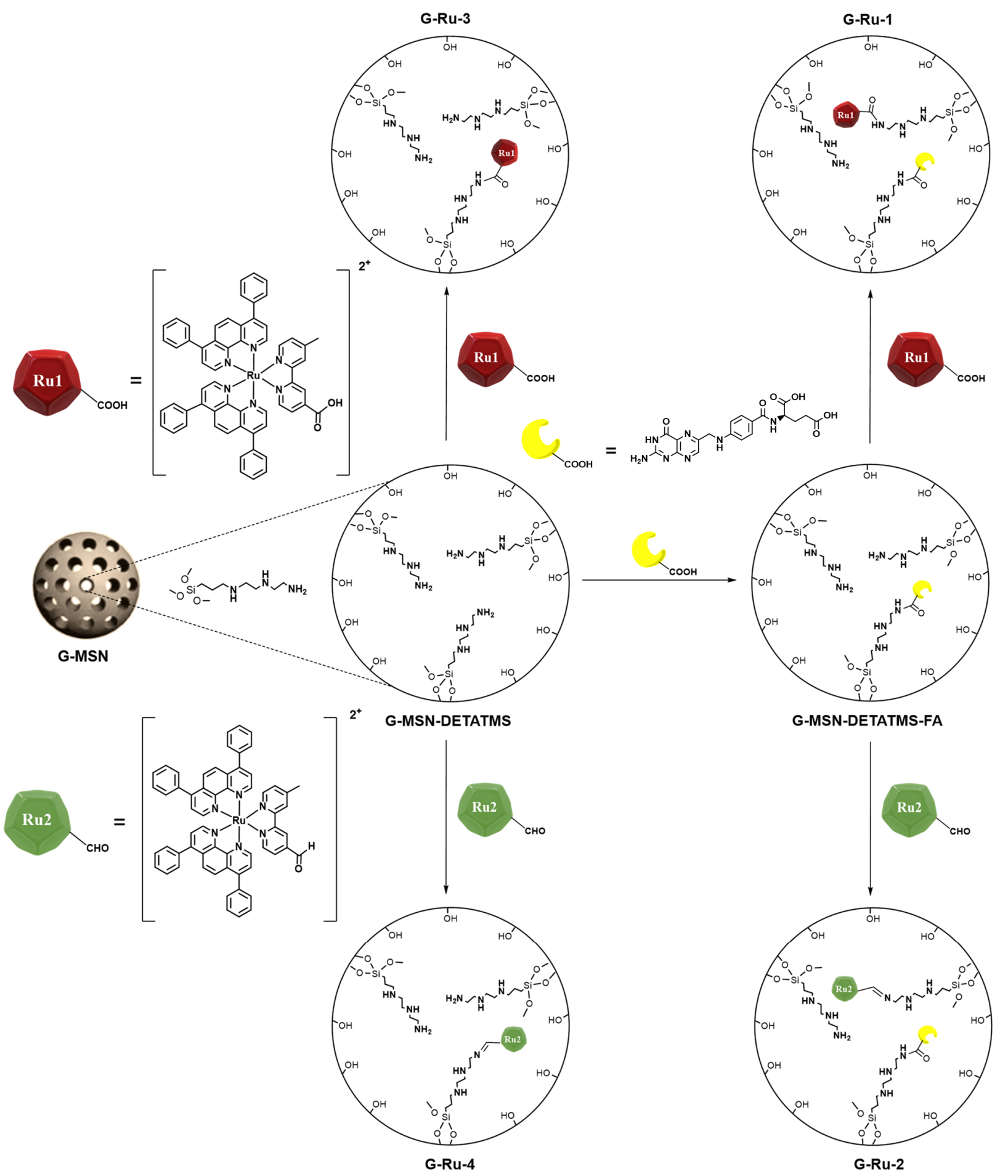

Scheme 1. Synthesis of Ru(II) polypyridine complex and folic acid functionalized mesoporous silica nanoparticles. 


\section{Characterization}

Following their preparation, the functionalized MSN particles were characterized in-depth. Using low angle powder X-ray diffraction, the conjugation to the outer sphere of the MSNs was characterized (Figure 1, Table S1). The diffractogram showed characteristic peaks for hexagonally distributed mesoporous silica particles. It is important to note that the intensity of the peaks decreased after successive incorporation of the fragments. For the starting material G-MSN, the diffractogram showed peaks associated with the Miller indices (100), (110) and (200) at $2 \theta$ of $2.45^{\circ}, 4.20^{\circ}$ and $4.8^{\circ}$, respectively. However, after the functionalization with the DETATMS linker, the intensity of the peak for the (100) Miller plane considerably decreased (by more than six times compared to the G-MSN peak). Furthermore, the diffraction at the other two Miller planes (110) and (200) disappeared due to blocking of the dispersion centers after the incorporation of the polyamino linker. After the functionalization with folic acid and subsequently with the corresponding $\mathrm{Ru}$ complex, the intensities of the main peak (100) decreased even further, although in a lesser extent than in the case of the incorporation of DETATMS.
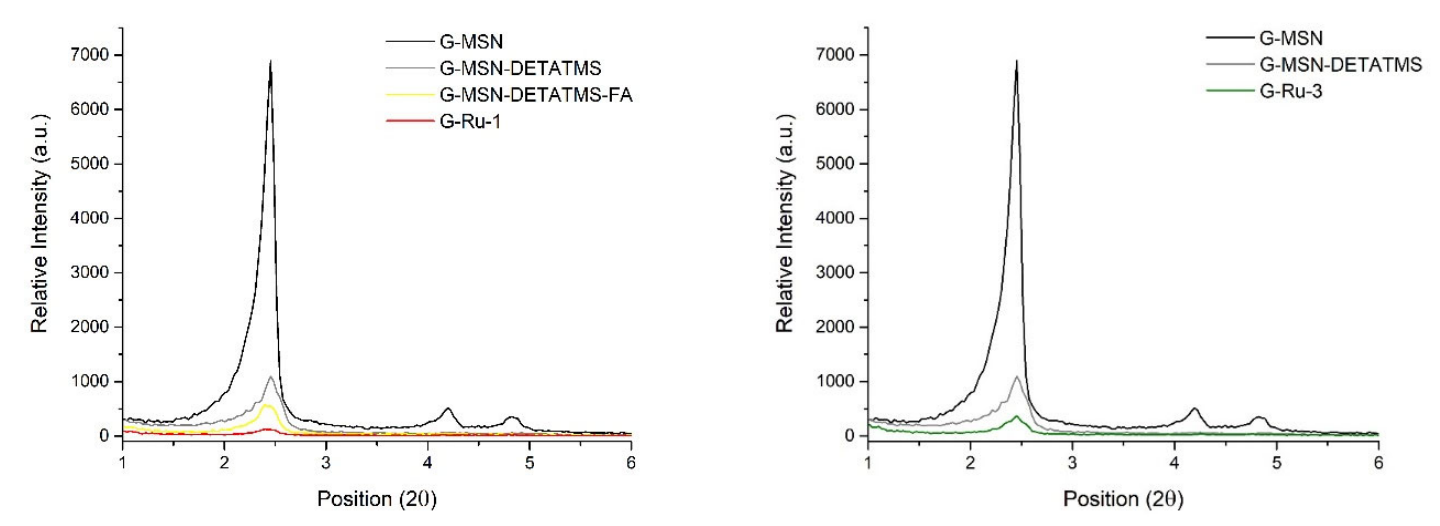

Figure 1. Powder X-ray diffraction spectra of the G-Ru-1 (left) and the G-Ru-3 (right) series.

The generated materials were further analyzed by Fourier-transformed infrared spectroscopy (FT-IR). While the spectrum for G-MSN (Figure S7) as well as the functionalized versions GMSN-DETATMS (Figure S8) and G-MSN-DETATMS-FA (Figure S9) showed the typical bands associated with the silica support, the spectra of the $\mathrm{Ru}(\mathrm{II})$ polypyridine complex conjugated nanomaterials (Figure S10-S11) significantly changed. The FT-IR spectra showed strong stretching vibration frequencies of the C-H and N-H bonds between 2750 to $3000 \mathrm{~cm}^{-1}$. In addition, bands of low to medium intensity in the area between 1600 to $1700 \mathrm{~cm}^{-1}$ were 
detected associated with $\mathrm{C}=\mathrm{O} / \mathrm{C}=\mathrm{N}$ bonds for $\mathbf{G}-\mathbf{R u} \mathbf{- 1} / \mathbf{G}-\mathbf{R u} \mathbf{- 2}$, respectively, corresponding to the amide/imide bond, which is formed upon conjugation of the $\mathrm{Ru}(\mathrm{II})$ polypyridine complex to the MSN particles.

The incorporation of all compounds was also studied by diffuse reflectance UV/Vis spectroscopy (Figure 2). The silica supported G-MSN-DETATMS particles showed a strong peak at $205 \mathrm{~nm}$ with an absorption tail towards longer wavelengths based on the presence of the DETATMS linker. Upon conjugation with FA (G-DETATMS-FA, G-Ru-1 and G-Ru-2), two bands at 295 and $365 \mathrm{~nm}$ appeared corresponding to the absorption of the aromatic systems found in FA. The functionalization of the MSNs with the $\mathrm{Ru}(\mathrm{II})$ polypyridine complexes (GRu-1 - G-Ru-4) showed the typical absorption bands found in this metal complex (absorption spectrum of Ru1 and Ru2: Figure S12); a ligand centered absorption with a maximum at 280 $\mathrm{nm}$ and a metal-to-ligand charge transfer transition with an absorption maximum in the blue region (Ru1: $462 \mathrm{~nm}$, Ru2: $460 \mathrm{~nm}$ ). Of special interest, the absorption spectrum of G-Ru-4 shows a very high intensity of the Ru complex-based transitions, indicating a presumably higher functionalization rate compared to the other studied materials.
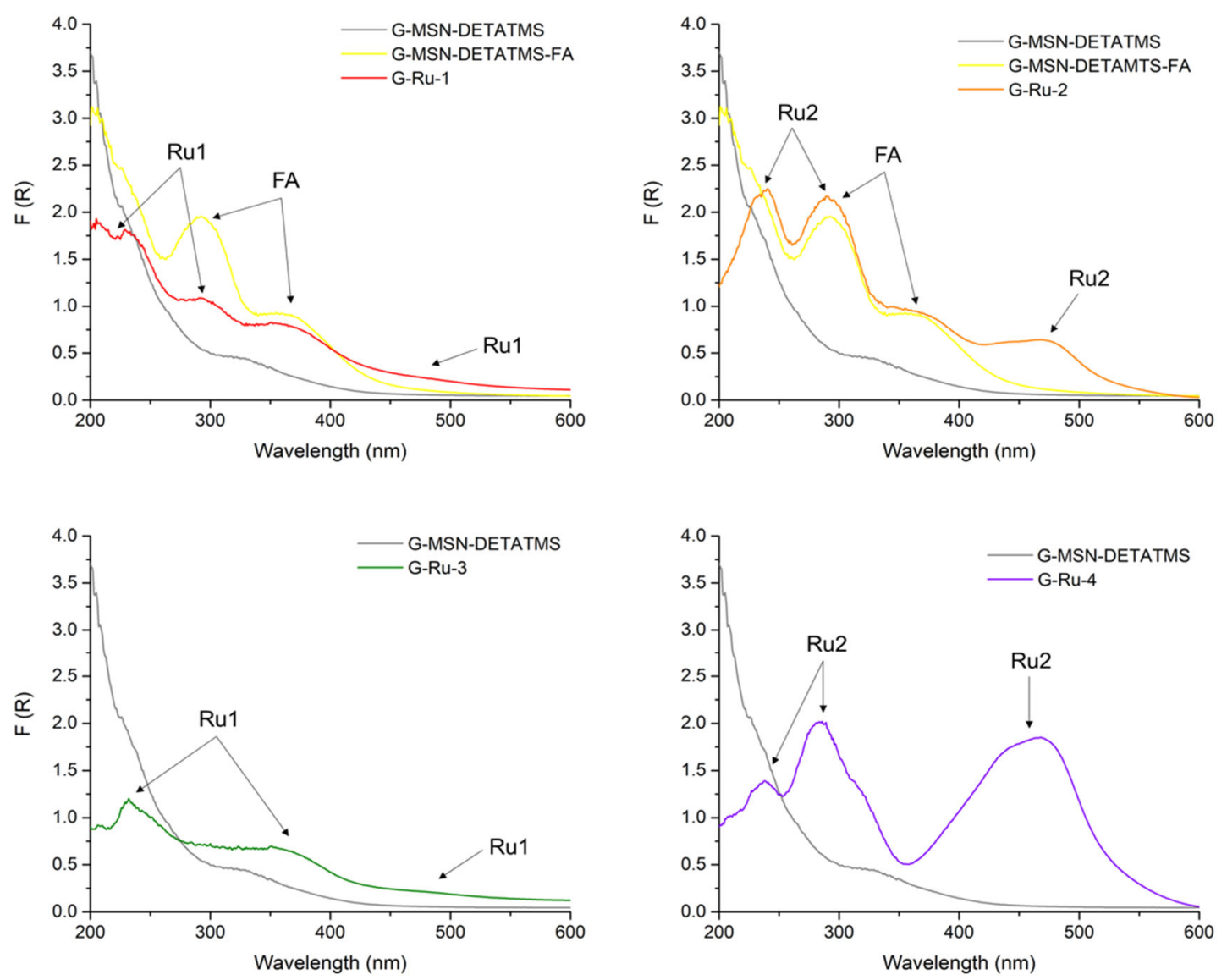
Figure 2. Diffuse reflectance UV/Vis solid absorption spectra, from left to right and from top to bottom: G-Ru-1 series, G-Ru-2 series; G-Ru-3 series and G-Ru-4 series.

The morphology and particle size of the MSNs was studied using transmission electron microscopy (TEM) and scanning electronic microscopy (SEM). Representative for the functionalization, Figure 3 shows of the TEM image of the starting material G-MSN with the $\mathrm{Ru}(\mathrm{II})$ polypyridine functionalized MSN particles G-Ru-3 in direct comparison. The quasispherical morphology of the particles with a hexagonal outline is illustrated. In both cases, the particle size is close to $200 \mathrm{~nm}(193 \pm 29 \mathrm{~nm}$ for G-MSN and $199 \pm 24 \mathrm{~nm}$ for G-Ru-3) indicating that, after the successive functionalization steps, the morphology and particle size of the nanoparticles has not been significantly affected. It should be noted that recent reports indicate that this particle size is optimal for drug delivery by maximizing the drug load while enabling cell membrane penetration. ${ }^{62}$ TEM images (Figure 3 (left) and Figure S13) also visualize the porosity of the mesoporous particles where the hexagonal distribution of the pores which corresponds to an MCM-41-like structure is observed. In addition, the porosity of the unmodified MSNs has also been confirmed by nitrogen adsorption-desorption isotherms (Figure S14 in the SI), observing a BET surface area of $1045 \mathrm{~m}^{2} / \mathrm{g}$, a pore diameter of $2.7 \mathrm{~nm}$ and a pore volume of $0.7 \mathrm{~cm}^{3} / \mathrm{g}$.

Within the SEM images (Figure 4, Figure S15) as representatively demonstrated for G-Ru-4, the homogeneity of the particles as well as overall spherical morphology is shown. 

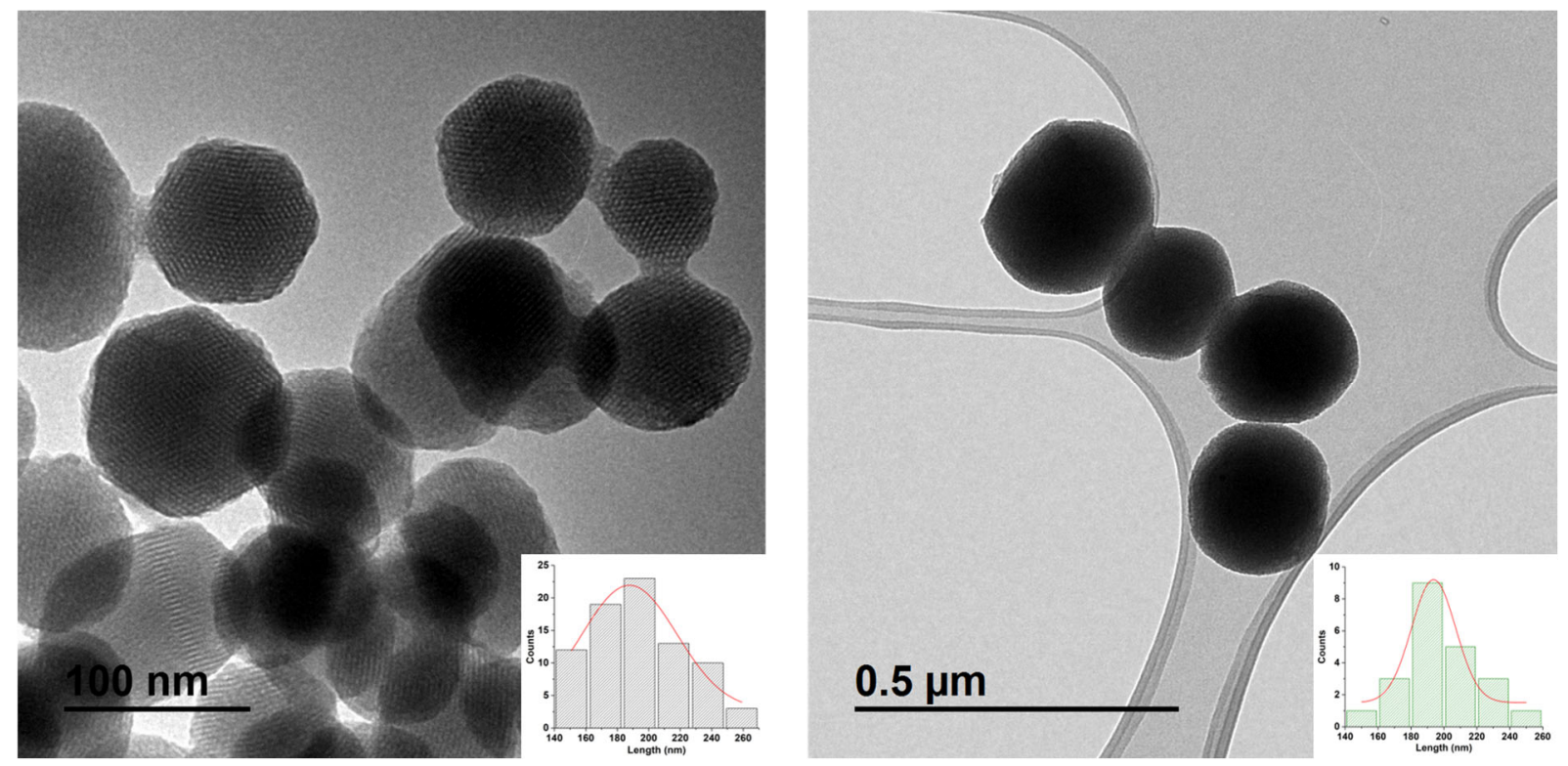

Figure 3. Transmission electron microscopy (TEM) images and histograms with the particle size distribution (inserts) of G-MSN (left) and G-Ru-3 (right).
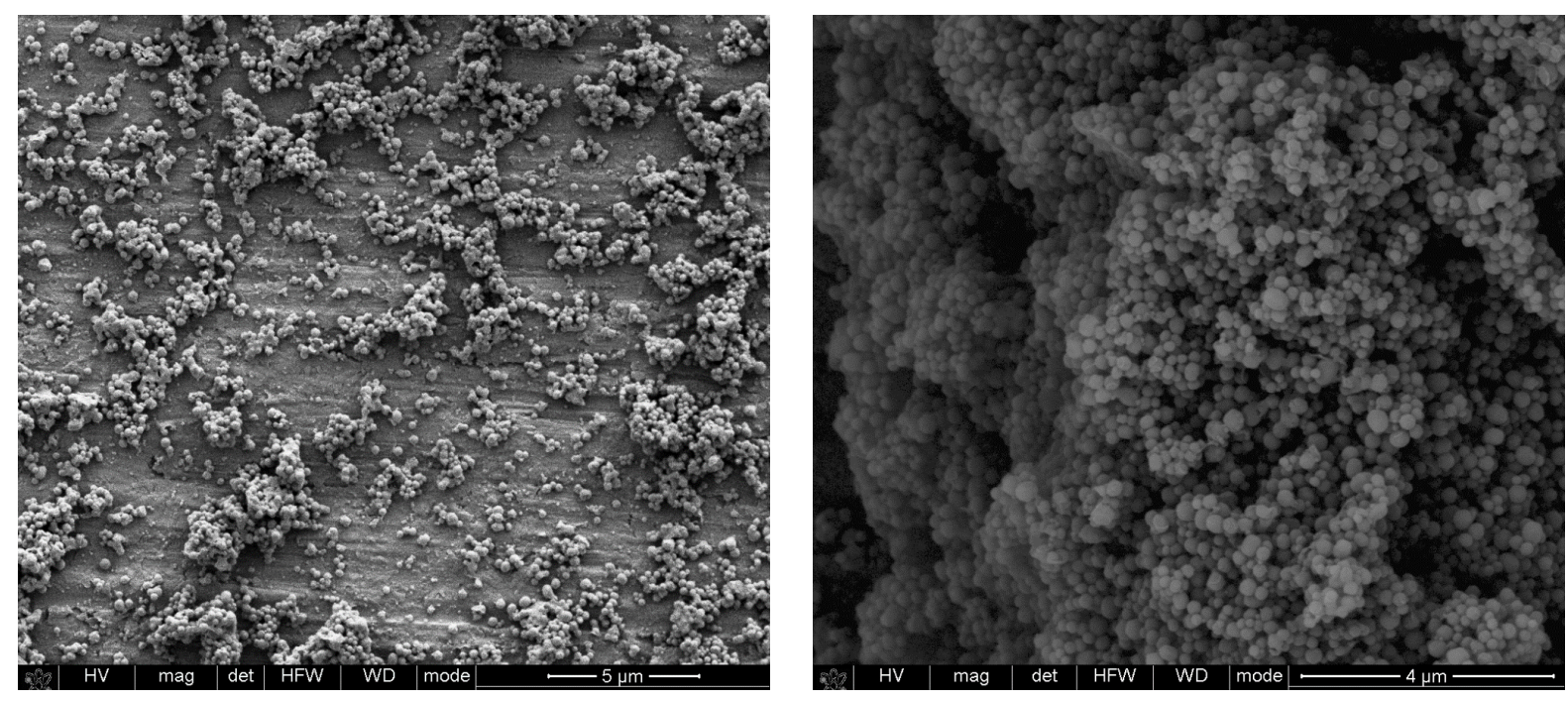

Figure 4. Scanning electronic microscopy (SEM) images of G-Ru-4.

Using a thermogravimmetry analysis of the MSN particles, the amount of functionalization with the DETATMS linker as well as conjugation of folic acid was determined. Upon measurement of the mass loss in dependence of the applied temperature range from $125-400{ }^{\circ} \mathrm{C}$ (Figure S16), the incorporation of the organic compounds can be determined. The analysis indicated that the MSN particles are functionalized with $0.47 \mathrm{mmol}$ of DETATMS and 0.10 mmol of FA per $g$ of material (Table 1). For further characterization, the amount of covalently 
attached $\mathrm{Ru}(\mathrm{II})$ polypyridine complexes was quantified using inductively coupled plasma atomic emission spectroscopy. The particles were found to have a loading rate of $0.0027-$ $0.0111 \%$ of ruthenium (Table S2), corresponding to $0.339-1.337 \mathrm{mg}$ of the Ru complex per g material (Table 1). Interestingly, the prepared particle formulation G-Ru-4 was found to have higher loading than the other materials G-Ru-1 - G-Ru-3. In general, the absence of folic acid (materials G-Ru-2 and G-Ru-4), which partially occupies the amino groups of the DETATMS linker, precludes the subsequent functionalization with the $\mathrm{Ru}(\mathrm{II})$ polypyridine complex, showing lower Ru-functionalization quantity in materials G-Ru-1 and G-Ru-3, compared with G-Ru-2 and G-Ru-4, respectively). In addition, the imine formation proceeds with a higher reaction yield with respect to the amide reaction under the studied conditions.

Following this, the potential release of a $\mathrm{Ru}(\mathrm{II})$ polypyridine complex from the MSN particles was studied upon incubation in phosphate-buffered saline (PBS, $\mathrm{pH}=7.4$ ) for $72 \mathrm{~h}$ at $37{ }^{\circ} \mathrm{C}$ and the ruthenium content in solution was determined by inductively coupled plasma atomic emission spectroscopy. These findings suggest that neither the amide (G-Ru-1, G-Ru-3) nor the imine (G-Ru-2, G-Ru-4) conjugated Ru(II) polypyridine complex conjugated MSN particles show a significant release of the metal complex ( $<0.02$ ppm corresponding to $<0.002 \%$ of the loaded $\mathrm{Ru}$, Table S3) therefore suggesting their stability in a biological environment. These findings are in agreement with previously studied metallodrug-functionalized silicabased systems, which were also found to be stable under biological conditions..$^{26,58}$

Table 1. Amount of functionalization with DETATMS and FA determined by thermogravimetry and with a Ru(II) polypyridine complex determined by inductively coupled plasma atomic emission spectroscopy for G-Ru-1 - G-Ru-4.

\begin{tabular}{|c|c|c|c|}
\hline Material & $\begin{array}{c}\text { mmol DETATMS / } \\
\text { g material }\end{array}$ & $\begin{array}{l}\text { mmol FA / } \\
\text { g material }\end{array}$ & $\begin{array}{c}\text { mg Ru complex / } \\
\text { g material }\end{array}$ \\
\hline G-Ru-1 & \multirow{4}{*}{0.47} & \multirow{2}{*}{0.10} & 0.339 \\
\hline G-Ru-2 & & & 0.903 \\
\hline G-Ru-3 & & - & 1.093 \\
\hline G-Ru-4 & & - & 1.377 \\
\hline
\end{tabular}

\section{Photophysical evaluation}


The photophysical properties of the $\mathrm{Ru}(\mathrm{II})$ polypyridine complexes and their functionalized MSN particles were investigated (Table S4) to determine their potential as PSs for PDT. As previously shown, the absorption spectra of Ru1 and Ru2 (Figure S12) has a maximum of the metal-to-ligand charge transfer transition in the blue region (Ru1: $462 \mathrm{~nm}, \mathbf{R u 2}: 460 \mathrm{~nm}$ ), which could potentially be utilized to cause the desired phototoxic effect. Furthermore, the complexes are characterized with a long absorption tail towards the red region of the spectrum. The absorption spectrum of the recently reported [Ru(bphen)2(4,4'-dimethyl-2,2'bipyridine) $]\left[\mathrm{PF}_{6}\right]_{2}$ complex ${ }^{59}$ showed the same distinctive peaks with only small differences. These observations indicate that the terminal group on the bipyridine moiety has only a minor effect on the absorption properties of the complex. It is important to mention that the applied wavelength directly influences the tissue light penetration depth and consequently the ability to treat deep seated or large tumors. Following this, the luminescence properties of the $\mathrm{Ru}(\mathrm{II})$ polypyridine complexes were investigated and compared with their MSN conjugates. Upon excitation at $450 \mathrm{~nm}$ in acetonitrile, all compounds showed a similar emission spectrum (Figure S17) with a maximum at $629 \mathrm{~nm}$. This results in a large Stokes shift, suggesting minimal interference between excitation and emission. The luminescence quantum yields ( $\left.\Phi_{\mathrm{em}}\right)$ of $\mathbf{R u 1}$ - Ru2 $(2.1-2.3 \%)$ were found to be significantly higher than the MSN conjugates G-Ru-1 G-Ru-4 $(1.0-1.2 \%)$. This effect was previously observed for other Ru(II) polypyridine complex functionalized MSNs. ${ }^{54}$ All investigated complexes and conjugates were found to have excited state lifetime values (Figure S18-S23) in the nanosecond scale in an air saturated (111 - $161 \mathrm{~ns})$ and degassed solution $(880-990 \mathrm{~ns})$. It should be noted that the observed photophysical properties of the $\mathrm{Ru}(\mathrm{II})$ polypyridine complexes and corresponding conjugates are in the same range as the previously reported compounds. ${ }^{63}$ Importantly, the observed lifetimes strongly decreased in the presence of air, suggesting that molecular oxygen $\left({ }^{3} \mathrm{O}_{2}\right)$ can interact with the excited state of the $\mathrm{Ru}(\mathrm{II})$ polypyridine complex to generate singlet oxygen $\left({ }^{1} \mathrm{O}_{2}\right)$.

For quantification of the ${ }^{1} \mathrm{O}_{2}$ production, two complementary techniques were used: 1) direct by measurement of the phosphorescence of ${ }^{1} \mathrm{O}_{2}$ at about $1270 \mathrm{~nm} ; 2$ ) indirect by following the absorption properties of imidazole in an organic solvent and histidine in an aqueous solution as $\mathrm{a}^{1} \mathrm{O}_{2}$ scavenger and dimethyl-4-nitrosoaniline aniline as a reporter molecule (Figure S24, Table S5). All compounds were found to efficiently generate ${ }^{1} \mathrm{O}_{2}$ in acetonitrile with quantum yields between $25-56 \%$ and in an aqueous solution with quantum yields between $2-5 \%$ upon excitation at $450 \mathrm{~nm}$ or $540 \mathrm{~nm}$. As expected, due to the stronger photophysical properties of 
the Ru1 and Ru2 complexes compared to G-Ru-1 - G-Ru-4, these were found to have a higher ${ }^{1} \mathrm{O}_{2}$ production than the corresponding MSN conjugates. Nevertheless, all conjugates were characterized to have strong photophysical properties, including their ability to generate ${ }^{1} \mathrm{O}_{2}$, which is a crucial requirement for PDT agents.

\section{Biological evaluation}

Following the in-depth characterization and photophysical evaluation of the MSN particles, their biological properties was investigated and compared to cisplatin and the PS Protoporphyrin IX upon irradiation at $480 \mathrm{~nm}$ or $540 \mathrm{~nm}$. The potential targeting of folate receptor overexpressing cancer cells was evaluated by comparison of the cytotoxicity between non-cancerous human normal lung fibroblast (MRC5), which have folate receptors in the normal range, with cancerous human ovarian carcinoma (A2780) cells, which are well-known to have an overexpressed number of folate receptors. ${ }^{64}$ It is important to note that the cell media also contains folate as an essential component, which could potentially compete with the folate functionalized nanoparticles. The light exposure time towards the cells at the different wavelengths was optimized based on the cell survival with a minimum of $95 \%$ of cell survival upon treatment purely with the light. No cytotoxic effect was observed upon irradiation at 480 $\mathrm{nm}$ for $6 \mathrm{~min}\left(8.7 \mathrm{~J} / \mathrm{cm}^{2}\right)$ or at $540 \mathrm{~nm}$ for $40 \mathrm{~min}\left(9.5 \mathrm{~J} / \mathrm{cm}^{2}\right)$. Before testing the biological properties of the nanoparticles formulations, the preferred incubation time $(2 \mathrm{~h}, 4 \mathrm{~h}, 8 \mathrm{~h}, 12 \mathrm{~h}$, $16 \mathrm{~h}, 24 \mathrm{~h}$ ) of the particles in A2780 cells was investigated upon determination of the photocytotoxcity of G-Ru-2 and irradiation at $480 \mathrm{~nm}$ (Table S6). It is important to note that after the incubation of the particles, the cells were washed and the media replaced, removing no internalized particles. While after a $2 \mathrm{~h}$ pre-incubation, no cytotoxic effect was observed, an increased amount of cell death occured with longer pre-incubation times. Comparison shows that the augmentation of the incubation longer than $12 \mathrm{~h}$ did not further reduce the measured half maximum inhibitory concentrations ( $\left.\mathrm{IC}_{50}\right)$. Capitalizing on this, all further biological evaluations were performed with a $12 \mathrm{~h}$ pre-incubation period. Previous studies have shown that nanoparticles typically require this amount of time to reach their maximum uptake. ${ }^{45,65}$

The non-formulated Ru(II) polypyridine complexes Ru1 and $\mathbf{R u} 2$ demonstrated a cytotoxic effect in the dark in the micromolar range $\left(\mathrm{IC}_{50, \text { dark }}=23.7-38.1 \mu \mathrm{M}\right)$ within the tested cell lines (Table 2, Figure S25-S26). Other previously published 4,7-diphenyl-1,10-phenanthroline coordinated $\mathrm{Ru}(\mathrm{II})$ complexes were also reported with a cytotoxic effect in the dark. ${ }^{20,59}$ Upon irradiation at 480 or $540 \mathrm{~nm}$, the cytotoxicity was reduced to the very low micromolar range 
$\left(\mathrm{IC}_{50,480 \mathrm{~nm}}=1.5-2.7 \mu \mathrm{M}, \mathrm{IC}_{50,540 \mathrm{~nm}}=2.9-5.6 \mu \mathrm{M}\right)$ without a preference for cancerous or noncancerous cells. This corresponds to phototoxic indices between 4.2-18.9, which is in the same order of magnitude than for the well-known PS Protoporphyrin IX, which presents phototoxic indices between $>10.3->22.2$. In comparison, no cytotoxic effect in the dark for MSN, the functionalized particles MSN-DETATMS/MSN-DETATMS-FA as well as the covalently linked $\mathrm{Ru}(\mathrm{II})$ polypyridine complex particles G-Ru-1 - G-Ru-4 was observed (IC50,dark $>500$ $\mu \mathrm{g} / \mathrm{mL} ;>133-549 \mathrm{nM})$, which presents a crucial property for a PDT agent. Upon irradiation at 480 or $540 \mathrm{~nm}$, the nanoparticle formulations without folic acid G-Ru-3 - G-Ru-4 caused a phototoxic effect in the low nanomolar range $\left(\mathrm{IC}_{50,480 \mathrm{~nm}}=44-72 \mu \mathrm{g} / \mathrm{mL} ; 48-62 \mathrm{nM}, \mathrm{IC}_{50,540 \mathrm{~nm}}=\right.$ 49-83 $\mu \mathrm{g} / \mathrm{mL}$; 54-71 $\mathrm{nM}$ ) without differentiating between cancerous and non-cancerous cells. On the contrary, the folic acid functionalized particles G-Ru-1 - G-Ru-2 demonstrated a different cytotoxic profile. The MSN particles caused no cell death upon irradiation at 480 or

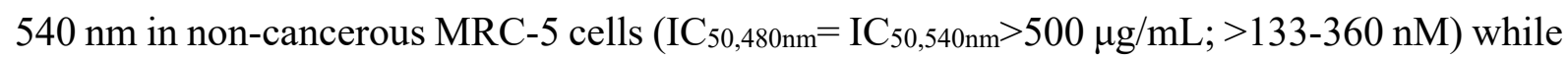
showing cell death in the low nanomolar range $\left(\mathrm{IC}_{50,480 \mathrm{~nm}}=43-159 \mu \mathrm{g} / \mathrm{mL} ; 31-42 \mathrm{nM}\right.$, $\left.\mathrm{IC}_{50,540 \mathrm{~nm}}=61-187 \mu \mathrm{g} / \mathrm{mL} ; 44-50 \mathrm{nM}\right)$ in cancerous A2780 cells, which are characterized with an overexpressed number of the folate receptors, demonstrating their potential for cancer targeted treatment.

Table 2. Half maximum inhibitory concentrations $\left(\mathrm{IC}_{50}\right)$ of the nanoparticle formulation in $\mu \mathrm{g} / \mathrm{mL}$ (nM of the corresponding compound) in the dark and upon light expsosure at $480 \mathrm{~nm}$ (6 $\left.\min , 8.7 \mathrm{~J} / \mathrm{cm}^{2}\right)$ and $540 \mathrm{~nm}\left(40 \mathrm{~min}, 9.5 \mathrm{~J} / \mathrm{cm}^{2}\right)$ for MSN, MSN-DETATMS, MSNDETATMS-FA, Ru1, Ru2, G-Ru-1 - G-Ru-4 in comparison to the PS Protoporphyrin IX (PpIX) and the anticancer drug cisplatin in non-cancerous human normal lung fibroblast (MRC5) and cancerous human ovarian carcinoma (A2780) cells. Average of three independent measurements. 1) contains $2 \%$ dimethyl sulfoxide, n.d. = not determinable.

\begin{tabular}{|c|c|c|c|c|c|c|c|c|c|c|}
\hline & \multicolumn{5}{|c|}{ MRC-5 } & \multicolumn{5}{|c|}{ A2780 } \\
\hline & dark & $480 \mathrm{~nm}$ & PI & $540 \mathrm{~nm}$ & PI & dark & $480 \mathrm{~nm}$ & PI & $540 \mathrm{~nm}$ & PI \\
\hline $\mathbf{M S N}^{1)}$ & $>500 \mu \mathrm{g} / \mathrm{mL}$ & - & - & - & - & $>500 \mu \mathrm{g} / \mathrm{mL}$ & - & - & - & - \\
\hline MSN-DETATMS ${ }^{1)}$ & $>500 \mu \mathrm{g} / \mathrm{mL}$ & - & - & - & - & $>500 \mu \mathrm{g} / \mathrm{mL}$ & - & - & - & - \\
\hline $\begin{array}{c}\text { MSN-DETATMS- } \\
\text { FA }^{1)}\end{array}$ & $>500 \mu \mathrm{g} / \mathrm{mL}$ & - & - & - & - & $>500 \mu \mathrm{g} / \mathrm{mL}$ & - & - & - & - \\
\hline G-Ru-1 ${ }^{1)}$ & $\begin{array}{c}>500 \mu \mathrm{g} / \mathrm{mL} \\
(>133 \mathrm{nM})\end{array}$ & $\begin{array}{c}>500 \mu \mathrm{g} / \mathrm{mL} \\
(>133 \mathrm{nM})\end{array}$ & n.d. & $\begin{array}{c}>500 \mu \mathrm{g} / \mathrm{mL} \\
(>133 \mathrm{nM})\end{array}$ & n.d. & $\begin{array}{c}>500 \mu \mathrm{g} / \mathrm{mL} \\
(>133 \mathrm{nM})\end{array}$ & $\begin{array}{c}159 \pm 21 \mu \mathrm{g} / \mathrm{mL} \\
(42 \pm 6 \mathrm{nM})\end{array}$ & 3.1 & $\begin{array}{c}187 \pm 32 \mu \mathrm{g} / \mathrm{mL} \\
(50 \pm 9 \mathrm{nM})\end{array}$ & 2.7 \\
\hline G-Ru-2 ${ }^{1)}$ & $\begin{array}{c}>500 \mu \mathrm{g} / \mathrm{mL} \\
(>360 \mathrm{nM})\end{array}$ & $\begin{array}{c}>500 \mu \mathrm{g} / \mathrm{mL} \\
(>360 \mathrm{nM})\end{array}$ & n.d. & $\begin{array}{c}>500 \mu \mathrm{g} / \mathrm{mL} \\
(>360 \mathrm{nM})\end{array}$ & n.d. & $\begin{array}{c}>500 \mu \mathrm{g} / \mathrm{mL} \\
(>360 \mathrm{nM})\end{array}$ & $\begin{array}{c}43 \pm 7 \mu \mathrm{g} / \mathrm{mL} \\
(31 \pm 5 \mathrm{nM})\end{array}$ & 11.6 & $\begin{array}{c}61 \pm 11 \mu \mathrm{g} / \mathrm{mL} \\
(44 \pm 8 \mathrm{nM})\end{array}$ & 8.2 \\
\hline G-Ru-3 ${ }^{1)}$ & $\begin{array}{c}>500 \mu \mathrm{g} / \mathrm{mL} \\
(>430 \mathrm{nM})\end{array}$ & $\begin{array}{c}66 \pm 12 \mu \mathrm{g} / \mathrm{mL} \\
(57 \pm 10 \mathrm{nM})\end{array}$ & 7.6 & $\begin{array}{l}74 \pm 8 \mu \mathrm{g} / \mathrm{mL} \\
(64 \pm 7 \mathrm{nM})\end{array}$ & 6.8 & $\begin{array}{c}>500 \mu \mathrm{g} / \mathrm{mL} \\
(>430 \mathrm{nM})\end{array}$ & $\begin{array}{l}72 \pm 9 \mu \mathrm{g} / \mathrm{mL} \\
(62 \pm 8 \mathrm{nM})\end{array}$ & 6.9 & $\begin{array}{c}83 \pm 11 \mu \mathrm{g} / \mathrm{mL} \\
(71 \pm 9 \mathrm{nM})\end{array}$ & 6.0 \\
\hline G-Ru-4 ${ }^{1)}$ & $\begin{array}{c}>500 \mu \mathrm{g} / \mathrm{mL} \\
(>549 \mathrm{nM})\end{array}$ & $\begin{array}{c}44 \pm 7 \mu \mathrm{g} / \mathrm{mL} \\
(48 \pm 8 \mathrm{nM})\end{array}$ & 11.4 & $\begin{array}{c}49 \pm 8 \mu \mathrm{g} / \mathrm{mL} \\
(54 \pm 9 \mathrm{nM})\end{array}$ & 10.2 & $\begin{array}{c}>500 \mu \mathrm{g} / \mathrm{mL} \\
(>549 \mathrm{nM})\end{array}$ & $\begin{array}{c}51 \pm 11 \mu \mathrm{g} / \mathrm{mL} \\
(56 \pm 12 \mathrm{nM})\end{array}$ & 9.8 & $\begin{array}{c}64 \pm 12 \mu \mathrm{g} / \mathrm{mL} \\
(70 \pm 13 \mathrm{nM})\end{array}$ & 7.8 \\
\hline Ru1 $^{1)}$ & $28300 \pm 3400 \mathrm{nM}$ & $1500 \pm 290 \mathrm{nM}$ & 18.9 & $3700 \pm 880 \mathrm{nM}$ & 7.6 & $36900 \pm 4800 \mathrm{nM}$ & $2200 \pm 800 \mathrm{nM}$ & 16.8 & $2900 \pm 600 \mathrm{nM}$ & 12.7 \\
\hline $\mathbf{R u 2}^{1)}$ & $23700 \pm 2700 \mathrm{nM}$ & $2400 \pm 360 \mathrm{nM}$ & 9.9 & $5600 \pm 1000 \mathrm{nM}$ & 4.2 & $38100 \pm 4100 \mathrm{nM}$ & $2700 \pm 900 \mathrm{nM}$ & 14.1 & $3300 \pm 800 \mathrm{nM}$ & 11.5 \\
\hline PpIX $^{1)}$ & $>100000 \mathrm{nM}$ & $4500 \pm 800 \mathrm{nM}$ & $>22.2$ & $7300 \pm 1100 \mathrm{nM}$ & $>13.7$ & $>100000 \mathrm{nM}$ & $5300 \pm 1800 \mathrm{nM}$ & $>18.9$ & $9700 \pm 2100 \mathrm{nM}$ & $>10.3$ \\
\hline
\end{tabular}




\section{CONCLUSION}

In summary, highly efficient $\mathrm{Ru}(\mathrm{II})$ polypyridine complexes as photosensitizers for photodynamic therapy were covalently attached to mesoporous silica nanoparticles with and without folic acid by amide and imine bond formation in view of targeted photodynamic therapy. The generated conjugates were characterized using low angle powder X-ray diffraction, infrared spectroscopy, diffuse reflectance UV/VIS spectroscopy, transmission electron microscopy and scanning electronic microscopy. The Ru(II) polypyridine complex functionalized particles were found to be strongly luminescent and to produce high amounts of singlet oxygen upon light irradiation. All particles were found be non-toxic in the dark in the tested cell lines, which is crucial property for a PDT agent. The particles without attached folic acid caused a phototoxic effect upon irradiation at 480 or $540 \mathrm{~nm}$ in the low nanomolar range without differentiating between cancerous and non-cancerous cells. On the contrary, the nanoformulation with folic acid did not trigger significant cell death upon irradiation in noncancerous human normal lung fibroblast cells, while causing cell death in the low nanomolar range in cancerous human ovarian carcinoma cells. The comparison between the conjugation strategies by amide or imine bond formation generally showed that the imine conjugated nanoparticles have a higher ruthenium loading, resulting in a higher therapeutic efficiency. 


\section{EXPERIMENTAL SECTION}

\section{Materials}

The $\quad \mathrm{Ru}(\mathrm{II}) \quad$ complex dichlorobis(4,7-diphenyl-1,10-phenanthroline)ruthenium(II) $\mathrm{Ru}(\mathrm{bphen})_{2} \mathrm{Cl}_{2}$ was synthesized as previously published using the respective ligand. ${ }^{66}$ The ligands 4'-Methyl-2,2' -bipyridinyl-4-aldehyde ${ }^{60}$ and 4'-Methyl-2,2' -bipyridinyl-4-carboxylic $\operatorname{acid}^{61}$ were prepared as previously reported. The reagents used in the preparation of the starting material (G-MSN), hexadecyltrimethylammonium bromide and tetraethyl orthosilicate were purchased from Acros Organics and Sigma Aldrich respectively. The linker trimethoxysilylpropyldiethylenetriamine (DETATMS) was purchased from Fluorochem. The reagents necessary for coupling, 2-(N-morpholino)ethanesulfonic acid, $N$-(3-dimethylaminopropyl)- $N$ 'ethylcarbodiimide, $N$-hydroxysuccinamide, 2-mercaptoethanol and folic acid (FA) were purchased from Sigma Aldrich. Roswell Park Memorial Institute 1640 Medium (RPMI 1640), Dulbecco's Modified Eagles Medium (DMEM), Gibco Penicillin-Streptomycin-Glutamine (Penstrep), fetal bovine serum, Dulbecco's Phosphate-Buffered Saline were purchased from Fisher Scientific. Resazurin was purchased from ACROS Organics.

\section{Instrumentation and methods}

${ }^{1} \mathrm{H}$ and ${ }^{13} \mathrm{C}$ NMR spectra were recorded on a Bruker $400 \mathrm{MHz}$ NMR spectrometer. Chemical shifts $(\delta)$ are reported in parts per million ( $\mathrm{ppm})$ referenced to tetramethylsilane $(\delta 0.00) \mathrm{ppm}$ using the residual proton solvent peaks as internal standards. Coupling constants $(\mathrm{J})$ are reported in Hertz $(\mathrm{Hz})$ and the multiplicity is abbreviated as follows: s (singlet), $\mathrm{d}$ (doublet) and $\mathrm{m}$ (multiplet). ESI-MS experiments were measured with a LTQ-Orbitrap XL (Thermo Scientific) apparatus in positive ionization mode. The spray voltage was set at $3.6 \mathrm{kV}$ without used sheath or auxiliary gas. The ion transfer capillary was set at $40 \mathrm{~V}$ and held at $275^{\circ} \mathrm{C}$. The tube lens was set at $100 \mathrm{~V} .10 \mu \mathrm{L}$ of the sample were injected into a Thermo Finnigan Surveyor HPLC system with a continuous flow of methanol at $100 \mu \mathrm{L} \cdot \mathrm{min}^{-1}$. Using an Orbitrap in profile mode with a $\mathrm{m} / \mathrm{z}$ range between 150-2000, the ionized molecules were detected. The spectrum was analyzed with XCalibur 2.1. Using a Thermo Flash 2000 elemental analyzer, elemental analyses were performed. A Philips Diffractometer (PW3040/00 X'Pert MPD/MRD) using the $\mathrm{Cu} \mathrm{K} \alpha$ $(\lambda=1.5418 \AA)$ wavelength at $45 \mathrm{kV}$ and $40 \mathrm{~mA}$ was used to measure the X-ray diffraction pattern. The samples for FT-IR measurements were prepared as standard $\mathrm{KBr}$ pellets and analyzed with a spectrophotometer Termo Nicolet Avatar 380 FT-IR with a Michelson filter 
interferometer. Using a Varian Cary-500 spectrophotometer equipped with an integrating sphere and polytetrafluoroethylene as reference, the diffuse reflectance UV/Vis spectra were recorded. Thermogravimmetry (TG) analyses were obtained with a Shimadzu mod. DSC-50Q operating between 30 and $800{ }^{\circ} \mathrm{C}\left(\operatorname{ramp} 20^{\circ} \mathrm{C} / \mathrm{min}\right)$ at an intensity of $50 \mathrm{~A}$ in nitrogen. $\mathrm{N}_{2}$ gas adsorption-desorption isotherms (BET) were performed using a Micromeritics ASAP 2020 porosimeter and with a degasification step of 12 hours at $90^{\circ} \mathrm{C}$ under high vacuum $\left(1 \cdot 10^{-7}\right.$ bar $)$. Transmission electron microscopy (TEM) was carried out on a JEOL JEM 1010, operating at $100 \mathrm{kV}$ morphological analyses were carried out with the software Image $\mathrm{B}$. Scanning electron micrographs (SEM) were carried out on a XL30 ESEM Philips with an energy-dispersive spectrometry system (EDS).

\section{Synthesis}

\section{$\left[\mathrm{Ru}(\mathrm{bphen})_{2}\left(4^{\prime} \text { '-methyl-2,2'-bipyridinyl-4-carboxylic acid)][PF }\right]_{2}(\mathrm{Ru} 1)\right.$}

$\mathrm{Ru}$ (bphen) ${ }_{2} \mathrm{Cl}_{2}$ (200 mg, 1.0 equivalents) and 4'-Methyl-2,2'-bipyridinyl-4-carboxylic acid (57 mg, 1.2 equivalents) were dissolved in a 1:1 mixture of water/ethanol $(10 \mathrm{~mL})$ and were refluxed overnight under nitrogen atmosphere. The solvent was evaporated and the residue redissolved in $10 \mathrm{~mL}$ of water. A saturated, aqueous ammonium hexafluorophosphate solution was added and the resulting precipitate was collected by vacuum filtration. The solid was washed with water $(50 \mathrm{~mL})$ and diethyl ether $(50 \mathrm{~mL})$. The product was dried in high vacuum. Yield: 83\%. ${ }^{1} \mathrm{H}$ NMR (400 MHz, $\left.\mathrm{CD}_{3} \mathrm{CN}\right) \delta=9.09$ (s, 1H), $8.67(\mathrm{~s}, 1 \mathrm{H}), 8.35(1 \mathrm{H}, \mathrm{d}, \mathrm{J}=5.5$ $\mathrm{Hz}), 8.32(1 \mathrm{H}, \mathrm{d}, \mathrm{J}=5.5 \mathrm{~Hz}), 8.23(2 \mathrm{H}, \mathrm{d}, \mathrm{J}=1.5 \mathrm{~Hz}), 8.22(2 \mathrm{H}, \mathrm{d}, \mathrm{J}=2.0 \mathrm{~Hz}), 8.16(2 \mathrm{H}, \mathrm{d}, \mathrm{J}$ $=5.5 \mathrm{~Hz}), 8.03(1 \mathrm{H}, \mathrm{d}, \mathrm{J}=5.8 \mathrm{~Hz}), 7.82-7.74(\mathrm{~m}, 4 \mathrm{H}), 7.67-7.62(\mathrm{~m}, 22 \mathrm{H}), 7.28(1 \mathrm{H}, \mathrm{d}, \mathrm{J}=5.5$ $\mathrm{Hz}), 2.58(\mathrm{~s}, 3 \mathrm{H}) .{ }^{13} \mathrm{C}$ NMR $\left(100 \mathrm{MHz}, \mathrm{CD}_{3} \mathrm{CN}\right) \delta=166.5,159.2,157.3,153.8,153.1,153.0$, 152.2, 151.7, 150.1, 150.1, 150.0, 150.0, 149.4, 149.3, 149.3, 149.1, 142.9, 136.7, 136.7, 136.6, 130.8, 130.7, 130.6, 130.6, 130.1, 130.1, 129.9, 129.9, 129.9, 129.5, 127.2, 127.2, 127.1, 127.0, 126.5, 124.1, 21.1. ESI-HRMS (pos. detection mode): calcd for $\mathrm{C}_{60} \mathrm{H}_{42} \mathrm{~N}_{6} \mathrm{O}_{2} \mathrm{Ru} \mathrm{m} / \mathrm{z}[\mathrm{M}]^{2+}$ 490.1215; found: 490.1201. Elemental analysis calcd for $\mathrm{C}_{60} \mathrm{H}_{42} \mathrm{~F}_{12} \mathrm{~N}_{6} \mathrm{O}_{2} \mathrm{P}_{2} \mathrm{Ru}(\%)$ : C 56.74, $\mathrm{H}$ 3.33, N 6.62; found: C 56.80, H 3.24, N 6.39.

\section{$\left[\mathrm{Ru}(\mathrm{bphen})_{2}\left(4^{\prime} \text {-methyl-2,2'-bipyridinyl-4-aldehyde)][PF}\right]_{2}(\mathrm{Ru} 2)\right.$}

$\mathrm{Ru}$ (bphen) ${ }_{2} \mathrm{Cl}_{2}$ (200 mg, 1.0 equivalents) and 4'-Methyl-2,2'-bipyridinyl-4-aldehyde (57 mg, 1.2 equivalents) were dissolved in a 1:1 mixture of water/ethanol $(10 \mathrm{~mL})$ and were refluxed 
overnight under nitrogen atmosphere. The solvent was evaporated and the residue redissolved in $10 \mathrm{~mL}$ of water. A saturated, aqueous ammonium hexafluorophosphate solution was added and the resulting precipitate was collected by vacuum filtration. The solid was washed with water $(50 \mathrm{~mL})$ and diethyl ether $(50 \mathrm{~mL})$. The product was dried in high vacuum. Yield: $79 \%$. ${ }^{1} \mathrm{H}$ NMR $\left(400 \mathrm{MHz}, \mathrm{CD}_{3} \mathrm{CN}\right) \delta=10.18(\mathrm{~s}, 1 \mathrm{H}), 8.93$ (s, 1H), 8.64 (s, 1H), 8.29 (1H, d, J = 5.5 Hz), $8.27(1 \mathrm{H}, \mathrm{d}, \mathrm{J}=5.5 \mathrm{~Hz}), 8.20(4 \mathrm{H}, \mathrm{d}, \mathrm{J}=2.2 \mathrm{~Hz}), 8.15(1 \mathrm{H}, \mathrm{d}, \mathrm{J}=5.8 \mathrm{~Hz}), 8.11(1 \mathrm{H}, \mathrm{d}, \mathrm{J}$ $=3.2 \mathrm{~Hz}), 8.10(1 \mathrm{H}, \mathrm{d}, \mathrm{J}=3.2 \mathrm{~Hz}), 7.78-7.69(\mathrm{~m}, 4 \mathrm{H}), 7.67-7.57(\mathrm{~m}, 22 \mathrm{H}), 7.29-7.27(\mathrm{~m}, 1 \mathrm{H})$, $2.60(\mathrm{~s}, 3 \mathrm{H}) .{ }^{13} \mathrm{C}$ NMR $\left(100 \mathrm{MHz}, \mathrm{CD}_{3} \mathrm{CN}\right) \delta=191.5,160.3,157.0,154.9,153.2,153.1,152.9$, $152.3,151.8,150.4,150.3,150.2,149.4,149.3$, 149.2 , 148.9, 142.8, 136.6, 136.6, 130.8, 130.7 , $130.7,130.6,130.1,130.1,130.0,129.9,129.8,127.2$, 127.0, 126.7, 126.2, 122.9, 21.2. ESIHRMS (pos. detection mode): calcd for $\mathrm{C}_{60} \mathrm{H}_{42} \mathrm{~N}_{6} \mathrm{O}_{1} \mathrm{Ru} \mathrm{m} / \mathrm{z}$ [M] $]^{2+}$ 482.1236; found: 482.1226 . Elemental analysis calcd for $\mathrm{C}_{60} \mathrm{H}_{42} \mathrm{~F}_{12} \mathrm{~N}_{6} \mathrm{O}_{1} \mathrm{P}_{2} \mathrm{Ru}(\%)$ : C 57.47, H 3.38, N 6.70; found: C 57.56, H 3.22, N 6.64.

\section{Synthesis of mesoporous silica nanoparticles (G-MSN)}

The synthesis of the mesoporous silica nanoparticles was carried out using a modified method based on the experimental procedure reported by Zhao et al. ${ }^{67}$ For this, the surfactant hexadecyltrimethylammonium bromide ( $1 \mathrm{~g}, 2.74 \mathrm{mmol})$ was dissolved in $480 \mathrm{~mL}$ of Milli-Q water under rigorous stirring at room temperature. Subsequently, $3.5 \mathrm{~mL}$ of a $2 \mathrm{M}$ aqueous sodium hydroxide solution $(7 \mathrm{mmol})$ was added dropwise and the solution was heated to $80{ }^{\circ} \mathrm{C}$ under stirring. Subsequently, tetraethyl orthosilicate $(5 \mathrm{~mL}, 22.4 \mathrm{mmol})$ was added dropwise and the suspension stirred for two hours at $80^{\circ} \mathrm{C}$. After this time, the mixture was cooled to room temperature, filtered and washed with water and methanol. The obtained solid was calcinated at $550{ }^{\circ} \mathrm{C}$ (heating ramp of $1{ }^{\circ} \mathrm{C} / \mathrm{min}$ ) for 24 hours.

\section{Functionalization with amino groups}

The functionalization of the MSNs with the polyamino linker DETATMS was carried out following a similar procedure as previously described. ${ }^{68} 1.6 \mathrm{~g}$ of G-MSN was dried in a Schlenk tube under vacuum at $80^{\circ} \mathrm{C}$ overnight and was then dispersed under inert atmosphere in $40 \mathrm{~mL}$ of dry toluene. The mixture was then sonicated in a ultrasound for 20 minutues and, subsequently, $3.11 \mathrm{~mL}(12.07 \mathrm{mmol})$ of trimethoxysilyl-propyldiethylenetriamine (DETATMS) was added and the suspension reacted for 72 hours at $80{ }^{\circ} \mathrm{C}$ under nitrogen 
atmosphere and vigorous stirring. After this time, the mixture was cooled to room temperature and the resulting suspension was centrifuged $(6000 \mathrm{rpm}, 10$ minutes $)$. The solid was isolated by decantation and subsequently washed with toluene $(2 \times 10 \mathrm{~mL})$ and diethyl ether $(2 \times 10$ $\mathrm{mL}$ ) and dried in a stove at $80{ }^{\circ} \mathrm{C}$ overnight.

\section{Functionalization with folic acid (FA)}

The incorporation of folic acid was carried out following a similar procedure as described using an amido-coupling reaction with a carbodiimide as catalyst. ${ }^{57} 100 \mathrm{~mL}$ of MES buffer (pH 6.0) was prepared from a solution of 2-( $N$-morpholino)ethanesulfonic acid $0.1 \mathrm{M}$ and a solution of sodium chloride $0.5 \mathrm{M}$. In parallel, $100 \mathrm{mg}(0.23 \mathrm{mmol})$ of FA were dissolved in $25 \mathrm{~mL}$ dimethyl sulfoxide (with the help of an ultrasound bath). This solution was then added to a solution of $40 \mathrm{mg}(0.21 \mathrm{mmol})$ of $N$-(3-dimethylaminopropyl)- $N$ '-ethylcarbodiimide and $60 \mathrm{mg}$ $(0.52 \mathrm{mmol})$ of $N$-hydroxysuccinamide in $100 \mathrm{~mL}$ of the MES buffer previously prepared. The obtained mixture was vigorous stirred at room temperature for 15 minutes. Subsequently, $1 \mathrm{~g}$ of G-MSN-DETATMS suspended in $10 \mathrm{~mL}$ water was added and the mixture stirred for an additional 30 minutes. Then, $175.3 \mu \mathrm{L}(2.50 \mathrm{mmol})$ of 2-mercaptoethanol measured with a micropipette was added to the reaction mixture and the suspension was then stirred for two additional hours at room temperature. The resulting suspension was centrifuged at $6000 \mathrm{rpm}$ for 10 minutes and the resulting solid separated by decantation and subsequently washed with dimethyl sulfoxide $(2 \times 10 \mathrm{~mL})$, Milli-Q water $(2 \times 10 \mathrm{~mL})$ and ethanol $(2 \times 10 \mathrm{~mL})$. The final solid was then dried in a stove at $40{ }^{\circ} \mathrm{C}$ overnight.

\section{Preparation of the ruthenium-containing materials}

Functionalization of MSNs with the ruthenium complexes Ru1 and Ru2 was carried out using two different methods.

\section{Method 1 - Amide Formation:}

The synthesis was carried out through an $N$-(3-dimethylaminopropyl)- $N$ '-ethylcarbodiimide coupling. $25 \mathrm{~mL}$ of a reaction buffer was prepared with a final concentration of $0.1 \mathrm{M} 2-(\mathrm{N}-$ morpholino)ethanesulfonic acid and $0.5 \mathrm{M}$ sodium chloride with $\mathrm{pH}$ 6.0. Subsequently, $10 \mathrm{mg}$ (0.05 mmol) of $N$-(3-dimethylaminopropyl)- $N$ '-ethylcarbodiimide, $15 \mathrm{mg}(0.13 \mathrm{mmol})$ of $N$ - 
hydroxysuccinamide and a solution of $40 \mathrm{mg}(0.03 \mathrm{mmol})$ of Ru1 in $6 \mathrm{~mL}$ dimethyl sulfoxide was added. The mixture was vigorously stirred at room temperature for 15 minutes. After this time, $250 \mathrm{mg}$ of G-MSN-DETATMS / G-MSN-DETATMS-FA suspended in $20 \mathrm{~mL}$ of water was added and stirred for an additional 30 minutes. $49 \mu \mathrm{L}(0.70 \mathrm{mmol})$ of 2-mercaptoethanol was added to the solution and the mixture stirred for 2 hours at room temperature. The resulting suspension was centrifuged at $6000 \mathrm{rpm}$ for 10 minutes and the resulting solid washed with dimethyl sulfoxide $(2 \times 10 \mathrm{~mL})$, Milli-Q water $(2 \times 10 \mathrm{~mL})$ and ethanol $(2 \times 10 \mathrm{~mL})$. The obtained solid was dried in a stove at $40{ }^{\circ} \mathrm{C}$ overnight.

\section{Method 2 - Imine Formation:}

$250 \mathrm{mg}$ of G-MSN-DETATMS / G-MSN-DETATMS-FA were dried under vacuum at $80^{\circ} \mathrm{C}$ overnight. Subsequently, the solid was dispersed in $20 \mathrm{~mL}$ of Milli-Q water and the $\mathrm{pH}$ adjusted to 4.5 with nitric acid. A solution of $40 \mathrm{mg}(0.03 \mathrm{mmol}) \mathbf{R u} 2$ in $2 \mathrm{~mL}$ of dimethyl sulfoxide was added to the suspension. The mixture was then stirred for 2 hours at $50{ }^{\circ} \mathrm{C}$. After this time, the mixture was centrifuged at $6000 \mathrm{rpm}$ for 10 minutes and the resulting solid decanted and washed with dimethyl sulfoxide $(2 \times 10 \mathrm{~mL})$, Milli-Q water $(2 \times 10 \mathrm{~mL})$ and ethanol $(2 \times 10$ $\mathrm{mL}$ ) and dried in a stove at $40{ }^{\circ} \mathrm{C}$ overnight.

\section{Determination of DETATMS and FA content in MSN particles}

For the quantification of DETATMS and FA in the silica materials, a thermogravimetric study was carried out. Thermogravimetry analyses were performed with a Shimadzu mod DSC-50Q instrument operating between 30 and $800{ }^{\circ} \mathrm{C}\left(\operatorname{ramp~} 20^{\circ} \mathrm{C} / \mathrm{min}\right)$ at an intensity of $50 \mathrm{~A}$ under nitrogen atmosphere. DETATMS or FA functionalization was determined by mass loss of the silica material between $125-400^{\circ} \mathrm{C}$ from the molecular weight of the compound covalent conjugated to the silica.

\section{Determination of Ruthenium content in MSN particles}

For quantification of the ruthenium content, the functionalized silica materials were digested. $5 \mathrm{mg}$ of each material was suspended in $4 \mathrm{~mL}$ of concentrated nitric acid (60\% wt.). The solution was kept under vigorous stirring for 48 hours. Subsequently, $1 \mathrm{~mL}$ of concentrated hydrofluoric acid (48\% wt.) was added and the suspension stirred for an additional $24 \mathrm{~h}$. The 
resulting solution was centrifuged (6000 rpm, 10 minutes), filtered through a nylon filter $(0.2$ $\mu \mathrm{m})$ and analyzed directly by inductively coupled plasma atomic emission spectroscopy in triplicate with a Varian Vista AX Pro $\left(\lambda_{\mathrm{Ru}}=267.876 \mathrm{~nm}\right)$ instrument. The ruthenium content was determined upon comparison with a ruthenium standard solution.

\section{Release of $\mathrm{Ru}(\mathrm{II})$ polypyridine complexes from the MSN particles}

A release study was carried out to determine the stability of the amide and imine conjugated $\mathrm{Ru}(\mathrm{II})$ polypyridine complex conjugated MSN particles under biological conditions. The complexes $(2.5 \mathrm{mg})$ were incubated in phosphate-buffered saline buffer at $\mathrm{pH} 7.4(2.5 \mathrm{~mL})$ at $37{ }^{\circ} \mathrm{C}$ for 72 hours with slight shaking (30 rpm) using a Roto-Therm incubator (Benchmark). Subsequently, the suspension was filtered through a nylon filter $(0.2 \mu \mathrm{m})$ and the obtained solution analyzed by inductively coupled plasma atomic emission spectroscopy in triplicates. The ruthenium content was determined upon comparison with a ruthenium standard solution.

\section{Photophysical measurements}

The absorption and emission spectra were recorded, lifetime and singlet oxygen measurements were performed as previously described. ${ }^{37,39}$

\section{Cell culture}

Human normal lung fibroblast (MRC-5) cells were cultured in DMEM/F10 media containing $0.65 \mathrm{mg} / \mathrm{L}$ folic acid. The human ovarian carcinoma (A2780) cells were cultured in RPMI 1640 media containing $1.00 \mathrm{mg} / \mathrm{L}$ folic acid. All cell lines were complemented with $10 \%$ of fetal bovine serum, $100 \mathrm{U} / \mathrm{mL}$ penicillin-streptomycin mixture and maintained in humidified atmosphere at $37^{\circ} \mathrm{C}$ and $5 \%$ of $\mathrm{CO}_{2}$.

\section{(Photo-)cytotoxicity}

The (photo-)cytotoxicity of the compounds was assessed as previously described..$^{37,39}$

\section{ASSOCIATED CONTENT}




\section{Supporting Information}

The Supporting Information is available free of charge at https://pubs.acs.org/doi/XXX.

Synthesis of the Ru(II) complexes, NMR and ESI spectra of Ru1 and Ru2, Powder Xray diffraction data of the MSN functionalized materials, FT-IR spectra of G-MSN, GMSN-DETATMS, G-MSN-DETATMS-FA, G-Ru-1 - G-Ru-2, Absorption spectra of Ru1 and Ru2, TEM image of G-Ru-3, SEM images of G-Ru-4, Thermogravimetry analysis of the functionalized materials G-MSN-DETATMS and G-MSNDETATMS-FA, Quantification of Ru inside the MSN particles determined by ICP, Drug-Release upon incubation for $72 \mathrm{~h}$ at $37^{\circ} \mathrm{C}$ in PBS buffer, Spectroscopic properties of Ru1, Ru2 and G-Ru-1 - G-Ru-4, Emission spectra of Ru1, Ru2 and G-Ru-1 - GRu-4, Lifetime spectra of Ru1, Ru2 and G-Ru-1 - G-Ru-4 in aerated and degassed $\mathrm{CH}_{3} \mathrm{CN}$, Monitoring of the ${ }^{1} \mathrm{O}_{2}$ phosphorescence upon irradiation at $450 \mathrm{~nm}$ in $\mathrm{CH}_{3} \mathrm{CN}$ with different light doses, Singlet oxygen quantum yields in $\mathrm{CH}_{3} \mathrm{CN}$ and in an aqueous solution, IC50 values of G-Ru-2 upon increasement of the pre-incubation time, Doseresponse curves upon treatment of MRC-5 cells with Ru1 - Ru2 or G-Ru-1 - G-Ru-4 in the dark or upon irradiation, Dose-response curves upon treatment of A2780 cells with Ru1 - Ru2 or G-Ru-1 - G-Ru-4 in the dark or upon irradiation.

\section{ACKNOWLEDGMENT}

We thank Dr. Philippe Goldner for access to state-of-the-art laser apparatus. This work was financially supported by an ERC Consolidator Grant PhotoMedMet to G.G. (GA 681679), has received support under the program "Investissements d'Avenir" launched by the French Government and implemented by the ANR with the reference ANR-10-IDEX-0001-02 PSL (G.G.). We would also like to thank Ministerio de Ciencia e Innovación for the research grant RTI2018-094322-B-I00 and the thematic network CTQ2017-90802-REDT. 


\section{REFERENCES}

1. Dolmans, D. E. J. G. J.; Fukumura, D.; Jain, R. K., Photodynamic Therapy For Cancer. Nat. Rev. Cancer 2003, 3 (5), 380-387.

2. Heinemann, F.; Karges, J.; Gasser, G., Critical Overview Of The Use Of Ru(II) Polypyridyl Complexes As Photosensitizers In One-Photon And Two-Photon Photodynamic Therapy. Acc. Chem. Res. 2017, 50 (11), 2727-2736.

3. O'Connor, A. E.; Gallagher, W. M.; Byrne, A. T., Porphyrin and Nonporphyrin Photosensitizers in Oncology: Preclinical and Clinical Advances in Photodynamic Therapy. Photochem. Photobiol. 2009, 85 (5), 1053-1074.

4. Karges, J., Combining Inorganic Chemistry And Biology: The Underestimated Potential Of Metal Complexes In Medicine. ChemBioChem 2020, 21 (21), 3044-3046.

5. Lo, P.-C.; Rodríguez-Morgade, M. S.; Pandey, R. K.; Ng, D. K. P.; Torres, T.; Dumoulin, F., The Unique Features And Promises Of Phthalocyanines As Advanced Photosensitisers For Photodynamic Therapy Of Cancer. Chem. Soc. Rev. 2020, 49 (4), 1041-1056.

6. Karges, J.; Blacque, O.; Gasser, G., Metal Dipyrrin Complexes As Potential Photosensitizers For Photodynamic Therapy. Inorg. Chim. Acta 2020, 505, 119482.

7. Roque III, J.; Havrylyuk, D.; Barrett, P. C.; Sainuddin, T.; McCain, J.; Colón, K.; Sparks, W. T.; Bradner, E.; Monro, S.; Heidary, D.; Cameron, C. G.; Glazer, E. C.; McFarland, S. A., Strained, Photoejecting Ru(II) Complexes that are Cytotoxic Under Hypoxic Conditions. Photochem. Photobiol. 2020, 96 (2), 327-339.

8. Karges, J.; Kuang, S.; Ong, Y. C.; Chao, H.; Gasser, G., One- And Two-Photon Phototherapeutic Effects Of RuII Polypyridine Complexes In The Hypoxic Centre Of Large Multicellular Tumor Spheroids And Tumor-Bearing Mice. Chem. Eur. J. 2021, 27 (1), 362-370.

9. McKenzie, L. K.; Bryant, H. E.; Weinstein, J. A., Transition Metal Complexes As Photosensitisers In One- And Two-Photon Photodynamic Therapy. Coord. Chem. Rev. 2019, 379, 2-29.

10. Karges, J.; Yempala, T.; Tharaud, M.; Gibson, D.; Gasser, G., A Multi-Action and MultiTarget RuII-PtIV Conjugate Combining Cancer-Activated Chemotherapy And Photodynamic Therapy To Overcome Drug Resistant Cancers. Angew. Chem. Int. Ed. 2020, 59 (18), 7069-7075.

11. Lincoln, R.; Kohler, L.; Monro, S.; Yin, H.; Stephenson, M.; Zong, R.; Chouai, A.; Dorsey, C.; Hennigar, R.; Thummel, R. P.; McFarland, S. A., Exploitation Of Long-Lived 3IL Excited States For Metal-Organic Photodynamic Therapy: Verification In A Metastatic Melanoma Model. J. Am. Chem. Soc. 2013, 135 (45), 17161-17175.

12. Karges, J.; Blacque, O.; Goldner, P.; Chao, H.; Gasser, G., Towards Long Wavelength Absorbing Photodynamic Therapy Photosensitizers Via The Extension of A $\left[\mathrm{Ru}(\text { bipy) }]_{3}\right]^{2+}$ Core. Eur. J. Inorg. Chem. 2019, 2019 (32), 3704-3712.

13. Raza, A.; Archer, S. A.; Fairbanks, S. D.; Smitten, K. L.; Botchway, S. W.; Thomas, J. A.; MacNeil, S.; Haycock, J. W., A Dinuclear Ruthenium(II) Complex Excited By NearInfrared Light Through Two-Photon Absorption Induces Phototoxicity Deep Within Hypoxic Regions Of Melanoma Cancer Spheroids. J. Am. Chem. Soc. 2020, 142 (10), 4639-4647.

14. Monro, S.; Colón, K. L.; Yin, H.; Roque, J.; Konda, P.; Gujar, S.; Thummel, R. P.; Lilge, L.; Cameron, C. G.; McFarland, S. A., Transition Metal Complexes And Photodynamic Therapy From A Tumor-Centered Approach: Challenges, Opportunities, And Highlights From The Development of TLD1433. Chem. Rev. 2019, 119 (2), 797-828. 
15. Karges, J.; Stokes, R. W.; Cohen, S. M., Photorelease Of A Metal-Binding Pharmacophore From A Ru(II) Polypyridine Complex. Dalton Trans. 2021, 50, $2757-$ 2765.

16. Karges, J.; Kuang, S.; Maschietto, F.; Blacque, O.; Ciofini, I.; Chao, H.; Gasser, G., Rationally Designed Ruthenium Complexes For 1- And 2-Photon Photodynamic Therapy. Nat. Commun. 2020, 11 (1), 3262.

17. Poynton, F. E.; Bright, S. A.; Blasco, S.; Williams, D. C.; Kelly, J. M.; Gunnlaugsson, T., The Development Of Ruthenium(ii) Polypyridyl Complexes And Conjugates For In Vitro Cellular And In Vivo Applications. Chem. Soc. Rev. 2017, 46 (24), 7706-7756.

18. Shum, J.; Leung, P. K.-K.; Lo, K. K.-W., Luminescent Ruthenium(II) Polypyridine Complexes For A Wide Variety Of Biomolecular And Cellular Applications. Inorg. Chem. 2019, 58 (4), 2231-2247.

19. Karges, J.; Heinemann, F.; Maschietto, F.; Patra, M.; Blacque, O.; Ciofini, I.; Spingler, B.; Gasser, G., A Ru(II) Polypyridyl Complex Bearing Aldehyde Functions As A Versatile Synthetic Precursor For Long-Wavelength Absorbing Photodynamic Therapy Photosensitizers. Bioorg. Med. Chem. 2019, 27 (12), 2666-2675.

20. Dickerson, M.; Sun, Y.; Howerton, B.; Glazer, E. C., Modifying Charge And Hydrophilicity Of Simple Ru(II) Polypyridyl Complexes Radically Alters Biological Activities: Old Complexes, Surprising New Tricks. Inorg. Chem. 2014, 53 (19), 1037010377.

21. Shirasu, N.; Nam, S. O.; Kuroki, M., Tumor-Targeted Photodynamic Therapy. Anticancer Res. 2013, 33 (7), 2823-2831.

22. Karges, J.; Chao, H.; Gasser, G., Critical Discussion Of The Applications Of Metal Complexes For 2-Photon Photodynamic Therapy. J. Biol. Inorg. Chem. 2020, 25 (8), 1035-1050.

23. BEATTIE, A., The Value Of Dexedrine In Gastric Surgery. Med. Press. 1952, 228 (6), 143.

24. Park, K., Controlled Drug Delivery Systems: Past Forward And Future Back. J. Control. Release 2014, 190, 3-8.

25. Li, C.; Wang, J.; Wang, Y.; Gao, H.; Wei, G.; Huang, Y.; Yu, H.; Gan, Y.; Wang, Y.; Mei, L.; Chen, H.; Hu, H.; Zhang, Z.; Jin, Y., Recent Progress In Drug Delivery. Acta Pharm. Sin. B 2019, 9 (6), 1145-1162.

26. Wani, W. A.; Prashar, S.; Shreaz, S.; Gómez-Ruiz, S., Nanostructured Materials Functionalized With Metal Complexes: In Search Of Alternatives For Administering Anticancer Metallodrugs. Coord. Chem. Rev. 2016, 312, 67-98.

27. Barragán, F.; Carrion-Salip, D.; Gómez-Pinto, I.; González-Cantó, A.; Sadler, P. J.; de Llorens, R.; Moreno, V.; González, C.; Massaguer, A.; Marchán, V., Somatostatin Subtype-2 Receptor-Targeted Metal-Based Anticancer Complexes. Bioconjugate Chem. 2012, 23 (9), 1838-1855.

28. Wang, T.; Zabarska, N.; Wu, Y.; Lamla, M.; Fischer, S.; Monczak, K.; Ng, D. Y. W.; Rau, S.; Weil, T., Receptor Selective Ruthenium-Somatostatin Photosensitizer For Cancer Targeted Photodynamic Applications. Chem. Commun. 2015, 51 (63), 1255212555.

29. Huang, Y.; Huang, W.; Chan, L.; Zhou, B.; Chen, T., A Multifunctional DNA Origami As Carrier Of Metal Complexes To Achieve Enhanced Tumoral Delivery And Nullified Systemic Toxicity. Biomaterials 2016, 103, 183-196.

30. Zhu, X.; Zhou, H.; Liu, Y.; Wen, Y.; Wei, C.; Yu, Q.; Liu, J., Transferrin/Aptamer Conjugated Mesoporous Ruthenium Nanosystem For Redox-Controlled And Targeted Chemo-Photodynamic Therapy Of Glioma. Acta Biomater. 2018, 82, 143-157. 
31. Lameijer, L. N.; Hopkins, S. L.; Brevé, T. G.; Askes, S. H. C.; Bonnet, S., D- Versus LGlucose Conjugation: Mitochondrial Targeting Of A Light-Activated Dual-Mode-OfAction Ruthenium-Based Anticancer Prodrug. Chem. Eur. J. 2016, 22 (51), 1848418491.

32. Jakubaszek, M.; Rossier, J.; Karges, J.; Delasoie, J.; Goud, B.; Gasser, G.; Zobi, F., Evaluation Of The Potential Of Cobalamin Derivatives Bearing Ru(II) Polypyridyl Complexes As Photosensitizers For Photodynamic Therapy. Helv. Chim. Acta 2019, 102 (7), e1900104.

33. Karges, J.; Blacque, O.; Chao, H.; Gasser, G., Polymeric Bis(dipyrrinato) Zinc(II) Nanoparticles As Selective Imaging Probes For Lysosomes of Cancer Cells. Inorg. Chem. 2019, 58 (18), 12422-12432.

34. Kaspler, P.; Lazic, S.; Forward, S.; Arenas, Y.; Mandel, A.; Lilge, L., A Ruthenium(ii) Based Photosensitizer And Transferrin Complexes Enhance Photo-Physical Properties, Cell Uptake, And Photodynamic Therapy Safety And Efficacy. Photochem. Photobiol. Sci. 2016, 15 (4), 481-495.

35. Arora, K.; Herroon, M.; Al-Afyouni, M. H.; Toupin, N. P.; Rohrabaugh, T. N.; Loftus, L. M.; Podgorski, I.; Turro, C.; Kodanko, J. J., Catch and Release Photosensitizers: Combining Dual-Action Ruthenium Complexes with Protease Inactivation for Targeting Invasive Cancers. J. Am. Chem. Soc. 2018, 140 (43), 14367-14380.

36. Karges, J.; Jakubaszek, M.; Mari, C.; Zarschler, K.; Goud, B.; Stephan, H.; Gasser, G., Synthesis And Characterization Of An Epidermal Growth Factor Receptor-Selective RuII Polypyridyl-Nanobody Conjugate As A Photosensitizer For Photodynamic Therapy. ChemBioChem 2020, 21 (4), 531-542.

37. Karges, J.; Li, J.; Zeng, L.; Chao, H.; Gasser, G., Polymeric Encapsulation Of A Ruthenium Polypyridine Complex For Tumor Targeted One- And Two-Photon Photodynamic Therapy. ACS Appl. Mater. Interfaces 2020, 12 (49), 54433-54444.

38. Du, E.; Hu, X.; Roy, S.; Wang, P.; Deasy, K.; Mochizuki, T.; Zhang, Y., TaurineModified Ru(ii)-Complex Targets Cancerous Brain Cells For Photodynamic Therapy. Chem. Commun. 2017, 53 (44), 6033-6036.

39. Karges, J.; Tharaud, M.; Gasser, G., Polymeric Encapsulation Of A Ru(II)-Based Photosensitizer For Folate Targeted Photodynamic Therapy Of Drug Resistant Cancers. ChemRxiv 2020, doi: 10.26434/chemrxiv.13258613.v1.

40. Fang, J.; Nakamura, H.; Maeda, H., The EPR Effect: Unique Features Of Tumor Blood Vessels For Drug Delivery, Factors Involved, And Limitations And Augmentation Of The Effect. Adv. Drug. Deliv. Rev. 2011, 63 (3), 136-151.

41. Danhier, F., To Exploit The Tumor Microenvironment: Since The EPR Effect Fails In The Clinic, What Is The Future Of Nanomedicine? J. Control. Release 2016, 244, 108121.

42. Bœuf, G.; Roullin, G. V.; Moreau, J.; Van Gulick, L.; Zambrano Pineda, N.; Terryn, C.; Ploton, D.; Andry, M. C.; Chuburu, F.; Dukic, S.; Molinari, M.; Lemercier, G., Encapsulated Ruthenium(II) Complexes In Biocompatible Poly(d,1-lactide-co-glycolide) Nanoparticles For Application In Photodynamic Therapy. ChemPlusChem 2014, 79 (1), 171-180.

43. Mascheroni, L.; Dozzi, M. V.; Ranucci, E.; Ferruti, P.; Francia, V.; Salvati, A.; Maggioni, D., Tuning Polyamidoamine Design To Increase Uptake And Efficacy Of Ruthenium Complexes For Photodynamic Therapy. Inorg. Chem. 2019, 58 (21), 14586-14599.

44. Karges, J.; Chao, H.; Gasser, G., Synthesis, Characterization, And Biological Evaluation Of The Polymeric Encapsulation Of A Ruthenium(II) Polypyridine Complex With Pluronic F-127/Poloxamer-407 For Photodynamic Therapy Applications. Eur. J. Inorg. Chem. 2020, 2020 (34), 3242-3248. 
45. Soliman, N.; McKenzie, L. K.; Karges, J.; Bertrand, E.; Tharaud, M.; Jakubaszek, M.; Guérineau, V.; Goud, B.; Hollenstein, M.; Gasser, G.; Thomas, C. M., RutheniumInitiated Polymerization Of Lactide: A Route To Remarkable Cellular Uptake For Photodynamic Therapy Of Cancer. Chem. Sci. 2020, 11 (10), 2657-2663.

46. Sun, W.; Li, S.; Häupler, B.; Liu, J.; Jin, S.; Steffen, W.; Schubert, U. S.; Butt, H.-J.; Liang, X.-J.; Wu, S., An Amphiphilic Ruthenium Polymetallodrug For Combined Photodynamic Therapy And Photochemotherapy In Vivo. Adv. Mater. 2017, 29 (6), 1603702.

47. Karges, J.; Basu, U.; Blacque, O.; Chao, H.; Gasser, G., Polymeric Encapsulation Of Novel Homoleptic Bis(dipyrrinato) Zinc(II) Complexes With Long Lifetimes For Applications As Photodynamic Therapy Photosensitisers. Angew. Chem. Int. Ed. 2019, 58 (40), 14334-14340.

48. Shen, J.; Kim, H.-C.; Wolfram, J.; Mu, C.; Zhang, W.; Liu, H.; Xie, Y.; Mai, J.; Zhang, H.; Li, Z.; Guevara, M.; Mao, Z.-W.; Shen, H., A Liposome Encapsulated Ruthenium Polypyridine Complex As A Theranostic Platform For Triple-Negative Breast Cancer. Nano Lett. 2017, 17 (5), 2913-2920.

49. Askes, S. H. C.; Bahreman, A.; Bonnet, S., Activation Of A Photodissociative Ruthenium Complex By Triplet-Triplet Annihilation Upconversion In Liposomes. Angew. Chem. Int. Ed. 2014, 53 (4), 1029-1033.

50. Wumaier, M.; Yao, T.-M.; Hu, X.-C.; Hu, Z.-A.; Shi, S., Luminescent Ru(ii)-Thiol Modified Silver Nanoparticles For Lysosome Targeted Theranostics. Dalton Trans. 2019, 48 (28), 10393-10397.

51. Zhang, P.; Wang, J.; Huang, H.; Chen, H.; Guan, R.; Chen, Y.; Ji, L.; Chao, H., RuNH2@AuNPs As Two-Photon Luminescent Probes For Thiols In Living Cells And Tissues. Biomaterials 2014, 35 (32), 9003-9011.

52. Sun, D.; Liu, Y.; Yu, Q.; Zhou, Y.; Zhang, R.; Chen, X.; Hong, A.; Liu, J., The Effects Of Luminescent Ruthenium(II) Polypyridyl Functionalized Selenium Nanoparticles On bFGF-Induced Angiogenesis And AKT/ERK Signaling. Biomaterials 2013, 34 (1), 171 180.

53. Liu, T.; Zeng, L.; Jiang, W.; Fu, Y.; Zheng, W.; Chen, T., Rational Design Of CancerTargeted Selenium Nanoparticles To Antagonize Multidrug Resistance In Cancer Cells. Nanomedicine 2015, 11 (4), 947-958.

54. Ellahioui, Y.; Patra, M.; Mari, C.; Kaabi, R.; Karges, J.; Gasser, G.; Gómez-Ruiz, S., Mesoporous Silica Nanoparticles Functionalised With A Photoactive Ruthenium(ii) Complex: Exploring The Formulation Of A Metal-Based Photodynamic Therapy Photosensitiser. Dalton Trans. 2019, 48 (18), 5940-5951.

55. Frasconi, M.; Liu, Z.; Lei, J.; Wu, Y.; Strekalova, E.; Malin, D.; Ambrogio, M. W.; Chen, X.; Botros, Y. Y.; Cryns, V. L.; Sauvage, J.-P.; Stoddart, J. F., Photoexpulsion Of Surface-Grafted Ruthenium Complexes And Subsequent Release Of Cytotoxic Cargos To Cancer Cells From Mesoporous Silica Nanoparticles. J. Am. Chem. Soc. 2013, 135 (31), 11603-11613.

56. Wen, J.; Yan, H.; Xia, P.; Xu, Y.; Li, H.; Sun, S., Mesoporous Silica NanoparticlesAssisted Ruthenium(II) Complexes For Live Cell Staining. Sci. China Chem. 2017, 60 (6), 799-805.

57. Díaz-García, D.; Sommerova, L.; Martisova, A.; Skoupilova, H.; Prashar, S.; Vaculovic, T.; Kanicky, V.; del Hierro, I.; Hrstka, R.; Gómez-Ruiz, S., Mesoporous Silica Nanoparticles Functionalized With A Dialkoxide Diorganotin(IV) Compound: In Search Of More Selective Systems Against Cancer Cells. Microporous Mesoporous Mater. 2020, 300, 110154. 
58. Díaz-García, D.; Montalbán-Hernández, K.; Mena-Palomo, I.; Achimas-Cadariu, P.; Rodríguez-Diéguez, A.; López-Collazo, E.; Prashar, S.; Ovejero Paredes, K.; Filice, M.; Fischer-Fodor, E.; Gómez-Ruiz, S., Role Of Folic Acid In The Therapeutic Action Of Nanostructured Porous Silica Functionalized With Organotin (IV) Compounds Against Different Cancer Cell Lines. Pharmaceutics 2020, 12 (6), 512.

59. Karges, J.; Heinemann, F.; Jakubaszek, M.; Maschietto, F.; Subecz, C.; Dotou, M.; Vinck, R.; Blacque, O.; Tharaud, M.; Goud, B.; Viñuelas Zahínos, E.; Spingler, B.; Ciofini, I.; Gasser, G., Rationally Designed Long-Wavelength Absorbing Ru(II) Polypyridyl Complexes As Photosensitizers For Photodynamic Therapy. J. Am. Chem. Soc. 2020, 142 (14), 6578-6587.

60. Busche, C.; Comba, P.; Mayboroda, A.; Wadepohl, H., Novel RuII Complexes With Bispidine-Based Bridging Ligands: Luminescence Sensing And Photocatalytic Properties. Eur. J. Inorg. Chem. 2010, 2010 (8), 1295-1302.

61. Banerjee, T.; Rawalekar, S.; Das, A.; Ghosh, H. N., Interfacial Electron Transfer Dynamics Of Two Newly Synthesized Catecholate Bound RuII Polypyridyl-Based Sensitizers On TiO2 Nanoparticle Surface - A Femtosecond Pump Probe Spectroscopic Study. Eur. J. Inorg. Chem. 2011, 2011 (27), 4187-4197.

62. Villemin, E.; Ong, Y. C.; Thomas, C. M.; Gasser, G., Polymer Encapsulation Of Ruthenium Complexes For Biological And Medicinal Applications. Nat. Rev. Chem. 2019, 3 (4), 261-282.

63. Balzani, V.; Juris, A., Photochemistry And Photophysics Of Ru(II) Polypyridine Complexes In The Bologna Group. From Early Studies To Recent Developments. Coord. Chem. Rev. 2001, 211 (1), 97-115.

64. Antony, A. C., Folate Receptors. Annu. Rev. Nutr. 1996, 16 (1), 501-521.

65. Moore, T. L.; Urban, D. A.; Rodriguez-Lorenzo, L.; Milosevic, A.; Crippa, F.; SpuchCalvar, M.; Balog, S.; Rothen-Rutishauser, B.; Lattuada, M.; Petri-Fink, A., Nanoparticle Administration Method In Cell Culture Alters Particle-Cell Interaction. Sci. Rep. 2019, 9 (1), 900 .

66. Sullivan, B. P.; Salmon, D. J.; Meyer, T. J., Mixed Phosphine 2,2'-Bipyridine Complexes Of Ruthenium. Inorg. Chem. 1978, 17 (12), 3334-3341.

67. Zhao, Y.; Trewyn, B. G.; Slowing, I. I.; Lin, V. S. Y., Mesoporous Silica NanoparticleBased Double Drug Delivery System For Glucose-Responsive Controlled Release Of Insulin And Cyclic AMP. J. Am. Chem. Soc. 2009, 131 (24), 8398-8400.

68. Kotcherlakota, R.; Barui, A. K.; Prashar, S.; Fajardo, M.; Briones, D.; RodríguezDiéguez, A.; Patra, C. R.; Gómez-Ruiz, S., Curcumin Loaded Mesoporous Silica: An Effective Drug Delivery System For Cancer Treatment. Biomater. Sci. 2016, 4 (3), 448459. 


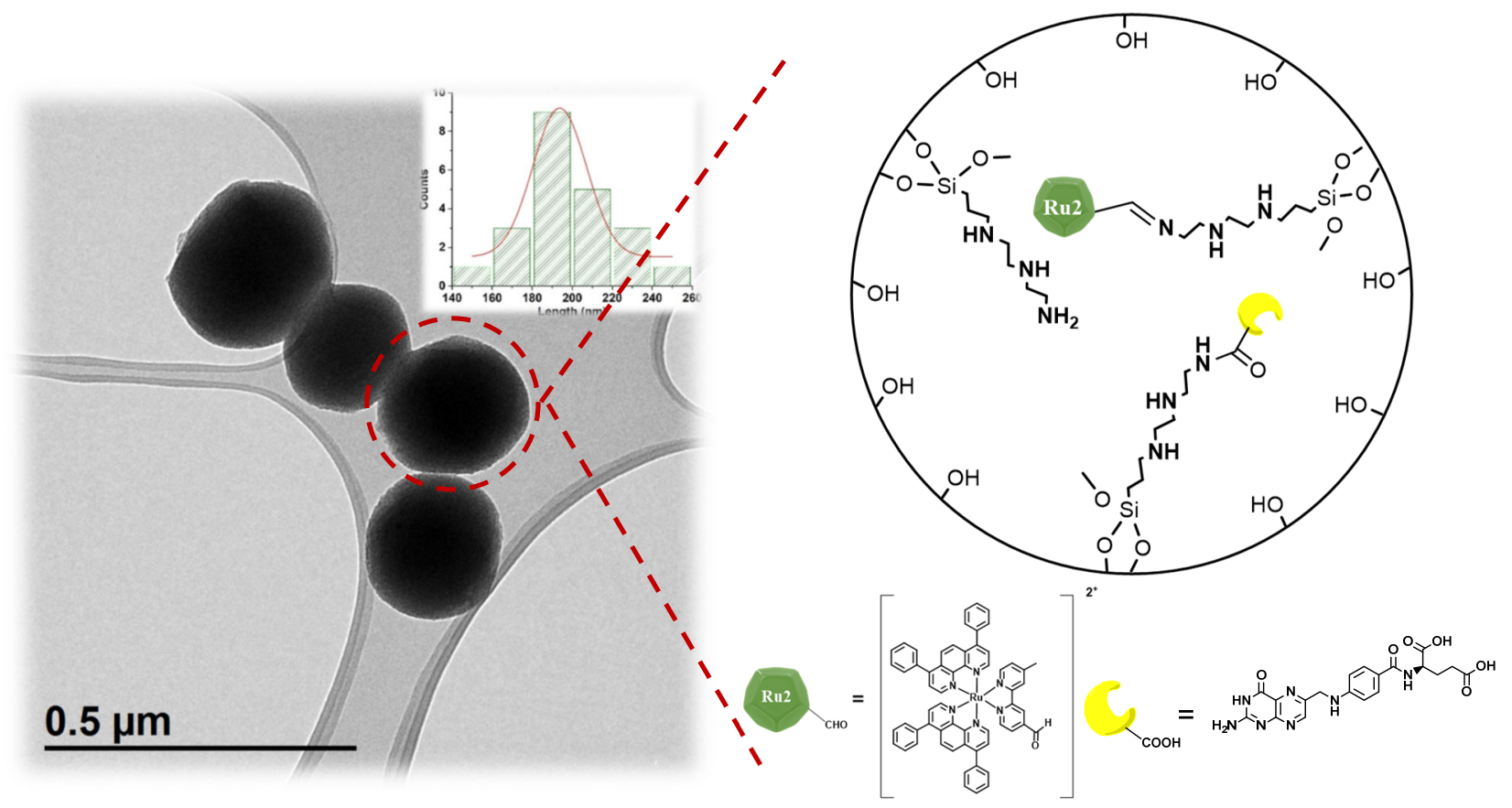

